\title{
Illustrations for Dante's Inferno: A Comparative Study of Sandro Botticelli, Giovanni Stradano, and Federico Zuccaro
}

\author{
Liana De Girolami Cheney \\ SIEALE, Universidad de Coruña, Spain
}

\begin{abstract}
This essay is twofold: the first part focuses on the interpretation of the concept of Hell in Dante's Inferno and Italian culture as depicted in Last Judgment scenes such as Giotto's in the Arena Chapel of Padua; Signorelli's in the Orvieto Cathedral; and Michelangelo’s in the Sistine Chapel in Rome. The second part deals with the drawing illustrations for the text of Dante's Divine Comedy composed by the Florentine painters Sandro Botticelli, Giovanni Stradano, and Federico Zuccaro. Here the emphasis is on Dante's Inferno, which comments upon Neoplatonic personalities, Florentine politics, and current popular art. Comparisons with some of Botticelli’s, Stradano’s, and Zuccaro's drawing illustrations indicate the assimilation of classical artistic concepts such as Horace's ut pictura poesis [as is painting so is poetry] as well as Plato's furor poeticus [poetical inspiration] promoted in the writings of Marsilio Ficino, a Renaissance Neoplatonic philosopher.
\end{abstract}

Keywords: Dante, Divine Comedy, canto (chant), Hell, creativity, poetry, drawings, Botticelli, Stradano, Zuccaro, Neoplatonism, ut pictura poesis, furor poeticus, Marsilio Ficino

\section{Introduction}

\author{
Nel mezzo del cammin di nostra vita \\ mi ritrovai per un a selva oscura \\ che la diritta via era smarrita. \\ [In the middle of the journey of our life \\ I found myself astray in a dark forest \\ Where the straight road was gone.] \\ Dante's Inferno, Canto I
}

The Divine Comedy or poema sacro [sacred poem], the masterpiece of the Florentine poet Dante Alighieri (1265-1321), is the most widely illuminated book of medieval literature. In three books (Inferno, Purgatorio, Paradiso) containing a series of individual sections, each called a canto, Dante reveals a phantasmal vision, his own spiritual odyssey, which transpired between Maundy Thursday and Easter Sunday. Guided by Virgil, his classical mentor, Dante visits Hell, passing through three rivers-Acheron, Styx, and Phlegethon —and each of the nine circles of sinners to reach the mountain of Purgatory. These circles are: limbo, lustful, gluttonous, avaricious and prodigal, wrathful and sullen, heretics, violent ones, malebolge, and traitors. In Purgatory, Dante meets his beloved Beatrice Portinari, who transports him to Paradise, where the onerous journey terminates

\footnotetext{
Liana De Girolami Cheney, Ph.D., Visiting Scholar in Art History, SIEALE, Universidad de Coruña, Spain. Correspondence concerning this article should be addressed to Liana De Girolami Cheney.

I am returning to a brief study initiated in Liana De Girolami Cheney, “Dante’s Inferno,” Italian Culture (Fall 1998), 35-55.
} 
with redemption and salvation. ${ }^{1}$ The poema sacro is an exploration into human nature-weakness, limitation, and potential—a religious and spiritual allegory of perdition, transformation, and salvation; and a philosophical journey of the Christian soul seeking to understand God's creation.

Exiled from Florence for life in 1302, Dante began writing this poema sacro sometime around 1308 and completed it in 1321. At the age of 35 ("in the middle of the journey of our life"), he was concerned with history, Florentine politics, the corruption of the clergy, the moral position of his contemporaries, and most of all the state of his own spirit or soul. ${ }^{2}$ Dante expressed his emotions by creating with words sensations of sights, sounds, and smells, thus visualizing for the reader the effects of good and evil in the world. ${ }^{3}$

Weaving Christian theology with excessive, sometimes scatological, images of illicit pleasures and grisly punishment involving historical, mythical, and contemporary figures, the Inferno understandably quickly attracted both commentary and illustrations. ${ }^{4}$ Renaissance artists from the fourteenth century to the sixteenth became fascinated with its poetic visualization and then illustrated its images both in drawings and paintings.

The first commentary on Dante's Divine Comedy was done by his son Jacopo. Entitled Ottimo, this commentary was written in Florence around 1340 and illuminated by Bartolomeo di Fruosino in 1420. The manuscript can be found in the Bibliothèque nationale in Paris (MS ital. 74) and the drawings in the Biblioteca Laurenziana in Florence (MS Plut. 40, 16, fol., 1v). The manuscript contains an author portrait, now on folio 3r, and also a full-page illumination of Dante and Virgil surveying the topography of Hell, now on folio $1 \mathrm{v}$ (bifolium 2 was added sometime around 1449). ${ }^{5}$

In the Quattrocento (fifteenth century), the Platonic Academy of Florence restored Dante's reputation with its publication of Cristoforo Landino's Commentary on the Divine Comedy on August 30, 1481. Sandro Botticelli (1445-1510) was commissioned to design 19 drawings to accompany the text of Landino's edition. ${ }^{6}$

\footnotetext{
${ }^{1}$ Dante Alighieri, La Divina Commedia, ed. and trans. C. H. Grandgent and revised by Charles S. Singleton (Cambridge, MA: Harvard University Press, 1972); Dante's Divine Comedy, ed. and trans. in literary prose by Charles S. Singleton (Princeton: Princeton University Press, 1970-1991); Dante's Divine Comedy, ed., trans. Mark Musa, Vol. 3 (Baltimore: Penguin Classics, 1967-2002); The Divine Comedy, ed. and trans. Allen Mandelbaum (New York: Vintage, 1980, 1995, 2013). See Robert Pinsky, The Inferno of Dante (New York: Farrar, Straus \& Giroux, 1994-1906, bilingual edition), for a dramatic translation of Dante's Inferno and monotypes of Michael Mazur; and Allen Mandelbaum, Anthony Oldcorn, and Charles Ross, Inferno: A Canto-by-Canto Commentary (Berkeley: University of California Press, 1998), for a clear study in English of Dante's Inferno; I have used this as the source reference for interpretation of the cantos.

2 See Mandelbaum, et al., Inferno: A Canto-by-Canto Commentary, 1-8, for a discussion on Dante and his time.

${ }^{3}$ For general references to Dante, see John Arthos, Dante, Michelangelo and Milton (London: Routledge \& Kegan Paul, 1963); Thomas G. Bergin, Dante (New York: The Orion Press, 1964); Charles T. Davis, Dante's Italy and Other Essays (Philadelphia: University of Pennsylvania Press, 1984); Robin Kirkpatrick, Dante: The Divine Comedy (New York: Cambridge University Press, 1987); Rachel Jacopff, ed., The Cambridge Companion to Dante (New York: Cambridge University Press, 1993); Ricardo J. Quinones, Foundation Sacrifice in Dante's Commedia (University Park: The Pennsylvania State University Press, 1994); Helen M. Luke, Dark Wood to White Rose: Journey and Transformation in Dante's Divine Comedy (New York: Parabola Books, 1989); and Charles H. Taylor and Patricia Finely, Images of the Journey in Dante's Divine Comedy (London: Yale University Press, 1997). See Wallace Fowlie, Dante's Inferno (Chicago: University of Chicago Press, 1981), 3-17, for a succinct and clear historical account of Dante's compositions for the Divine Comedy.

${ }^{4}$ G. Biagi, La Divina Commedia nella figurazione artistica e nel secolare comment [The Divine Comedy in Visual Representations and Commentary], Vol. 3 (Turin: UTET, 1924); P. Brieger, M. Meiss, and C. S. Singleton, Illuminated Manuscripts of the Divine Comedy, Vol. 2 (Princeton: Princeton University Press, 1969); Eugene Paul Nassar, Illustrations to Dante's Inferno (London: Associated University Press, 1994).

${ }^{5}$ Laurence B. Kanter, Painting and Illumination in Early Renaissance Florence, 1300-1450 (New York: Metropolitan Museum of Art, 1994).

${ }^{6}$ Adolfo Venturi, Il Botticelli: Interprete di Dante [Botticelli: Intepreter of Dante] (Florence: Felice Le Monnier, 1921), 7-13; Kenneth Clark, The Drawings by Sandro Botticelli For Dante's Divine Comedy: After the Originals in the Berlin Museum and Vatican (New York: Harper \& Row, Publishers, 1976), 7-24; Corrado Gizzi, Botticelli e Dante (Milan: Electa, 1990), 100-03; Peter Dreyer, “Botticelli’s Series of Engravings of 1481," Print Quarterly (June 1984), 111-115; Ronald Lightbown, Botticelli,
} 
Botticelli's drawings were in turn incised in woodcuts by Baccio Baldini (1436-1487) and printed with the Dante text by Niccolò di Lorenzo della Magna in Florence. One year later, in 1482, Lorenzo Pierfrancesco de' Medici (1463-1503) requested a second edition. Due to other artistic engagements, Botticelli delayed executing this commission until 1490 .

In subsequent years, editions of Landino's commentary were published in Venice, two of which were issued in 1536 and 1544 with the observations of Alessandro Vellutello. In 1551, a Lyon edition by Guglielmo Rovillo reported and commented on Vellutello's observations, with subsequent reprints of this edition being published in 1552 and 1575. In 1554, Giovanni Antonio Morandi printed Rovillo’s edition in Venice. In 1564, with other reprints to follow in 1578 and 1596, Francesco Sansovino edited another version of Dante's poema sacro, adding his own notations and incorporating the previous commentaries of Cristoforo Landino and Alessandro Vellutello. ${ }^{7}$

The first part of this essay focuses on the interpretation of the concept of Hell in Dante's Inferno and Italian culture as depicted in Last Judgment scenes such as Giotto's Last Judgment of 1305 in the Arena Chapel in Padua; Signorelli's frescoes of 1503 in the Orvieto Cathedral; and Michelangelo's Last Judgment of 1541 in the Sistine Chapel in Rome. The second part deals with the drawing illustrations for the text of Dante's Divine Comedy composed by the Florentine painters Botticelli, Giovanni Stradano (1523-1605), and Federico Zuccaro (c. 1540-1609). The emphasis is on Dante's Inferno, which comments on Neoplatonic personalities, Florentine politics, and current popular art. ${ }^{8}$ Comparisons with some of Botticelli's, Stradano's, and Zuccaro's drawing illustrations indicate the assimilation of classical artistic concepts such as Horace's ut pictora poesis [as is painting so is poetry] as well as Plato's furor poeticus [poetical inspiration] promoted in the writings of Marsilio Ficino, a Renaissance Neoplatonic philosopher.

\section{Concept of Hell in the Renaissance: Visio Tundali}

It may be asked why the Platonic Academy of Florence decided in the 15th century to revive Dante's

Life and Work, Vol. 2 (Berkeley: University of California Press, 1978); Barbara Watts, Studies in Sandro Botticelli's Drawings for Dante's Inferno (Ph.D. diss., University of Virginia, 1989); Barbara J. Watts, "Sandro Botticelli's Drawings for Dante's Inferno: Structure, Topography, and Manuscript Design,” Artibus et Historiae 16.32 (1995), 163-201; Barbara J. Watts, "Sandro Botticelli's Illustrations for Inferno VIII and IX: Narrative Revision and the Role of Manuscript Tradition,” Word and Image A Journal of Verbal/Visual Enquiry 2 (April-June, 1995), 149-173; Barbara J. Watts, “Artistic Competition, Hubris, and Humility: Sandro Botticelli’s Response to Visibile parlare,” in Dante Studies 114 (1996), 41-79; Barbara Watts, "Pictorial Wit and Parody as Narrative Tools: Botticelli’s Drawings for Dante’s Inferno,” oral presentation at the Boston Dante Society, 1998); Barbara J. Watts, “The Word Imaged: Dante’s Commedia and Sandro Botticelli’s San Barnaba Altarpiece,” in Lectura Dantis 22-23 (1998), 203-245; and Hein-Thomas Schulze Altcappenberg, Sandro Botticelli: The Drawings for Dante's Divine Comedy, Vol. 2 (London/Rome: Royal Academy of The Arts and Scuderie Papali al Quirinale, 2000), an excellent exhibition of these drawings.

7 Corrado Gizzi, ed., Federico Zuccari e Dante (Milan: Electa, 1993), 71-73.

${ }^{8}$ Corrado Ricci, La Divina Commedia di Dante Alighieri nell'arte del Cinquecento [The Divine Comedy of Dante Alighieri in the Art of Sixteenth Century]. Milan: Treves, 1908); Corrado Gizzi, ed., Botticelli e Dante (Milan: Electa, 1993); Corrado Gizzi, ed., Signorelli e Dante (Milan: Electa 1991); Gizzi, Federico Zuccari e Dante; Corrado Gizzi, ed., Giovanni Stradano e Dante (Milan: Electa, 1994); Charles H. Taylor and Patricia Finley, Images of the Journey of Dante's Divine Comedy (London: Yale University Press, 1997). Even today artists such as Michael Mazur are moved by the poema sacro. Mazur's monotypes illustrate Robert Pinsky's The Inferno of Dante. Mazur's imagery combines his personal interpretation of the poema sacro and his visual impressions of Florence. The effects of tenebrism in his monotypes create infernal images fusing the visual tradition of past Dante's imagery with his present apperception of visualizing a poem and experiencing Dante's history. For example, the frontispiece illustrates Canto III with the boat of Charon passing through the bridges of the Arno River. For Canto VIII, Mazur also draws from the topography of Florence, including in mist the tower of Palazzo Vecchio and surrounding it with burning flames, an image inspired by Dante's Furies at the City of Dis. Mazur's Cantos IX (Virgil’s description of Hell) and XXXIV (Lucifer or Simia Dei) undoubtedly represent two of the most fearful Dantesque images. Redemption, forgiveness, and hope are indeed abandoned. 
Divine Comedy. Perhaps one reason was the Church's desire to abolish witchcraft. ${ }^{9}$ In 1484, Pope Innocent VIII (1432-92) issued a bull condemning witchcraft in Europe, particularly in Germany, and he established a committee to destroy this spread of maleficence. The committee was governed by two of the pope's sons: the Dominican friar and inquisitor Heinrich Institor (Kramer, 1430-1505), and Jakob Sprenger (1436-95). Two years after the papal bull, the inquisitors printed an encyclopedia of demonology, the Malleus Maleficarum [The Hammer of Witches]. ${ }^{10}$

These two events-the papal bull of 1484 and publication of the results of the investigations in 1486 - served as the sources for a new Western mythology. It established a systematic demonology based on the fusion of social fears, popular superstitions, intellectual cosmology, and tales from folklore. ${ }^{11}$ The means employed by the Christian Church in its desire to eliminate heresy and witchcraft ironically contributed to the expansion of witchcraft in Europe. Witchcraft or witchcraze was used by individuals for personal gain and was employed as a political tool to destroy enemies.

Publication of the Malleus Maleficarum coincided with a general fascination with the Danse Macabre (Dance of Death) artistic genre. Engravings books were printed on the Visio Tundali (The Vision of Tundale; translation of a twelfth-century text telling of an otherworldly vision) and The Art of Dying (see Verard's Ars Moriendi of 1484). The latter dealt with the relatively new obsession with dying and the paraphernalia associated with death and dissolution. ${ }^{12}$ As this mania for death persisted, the modern art of healing began to evolve and was the subject of popular books that included information from medical texts and treatises concerning the use of herbal remedies for sickness as well as astrology manuals offering advice for better living. ${ }^{13}$

The Church used the popular eschatological Visio Tundali to combat the witchcraze of the fifteenth and sixteenth centuries. It desired to expose the evil of magic and debunk superstitions, divine spirits, idolatry, demonic doctrine, and false knowledge. Thereby the followers of witches would be intimidated and return to the one true faith, viz., Christianity. The Malleus Maleficarum taught its readers about evil or Simia Dei: "We may say that the devil can posses [an individual] ... we may say that since [an individual] is by any mortal sin brought into devil's service ... the devil provides suggestion of sin either to the senses or to the imagination, to that event the devil is said to inhabit in man ...,"14

The new mythology that arose in Europe during the fifteenth and sixteenth centuries was based on the traditional dualism of good and evil or God and the Devil but advanced new depictions of the devil. The

\footnotetext{
${ }^{9}$ See Jules Michelet, Satanism and Witchcraft: A Study in Medieval Superstition (New York: The Citadel Press, 1970); Henry Ansgar Kelly, The Devil, Demonology and Witchcraft (New York: Doubleday \& Company, 1968); Charles Moeller, ed., Satan (New York: Sheed \& Ward, 1952); and Everett Ferguson, Demonology of the Early Christian World (London: The Edwin Mellen Press, 1953).

${ }^{10}$ Francesco Maria Guazzo, Malleus Maleficarum (New York: Dover Publications, The Montague Summers Edition, 1988).

11 Guazzo, Malleus Maleficarum, iii-xiv; Michelet, Satanism and Witchcraft, 139-42; Kelly, The Devil, Demonology and Witchcraft, 58-66; H. R. Trevor-Roper, The European Witch-Craze (New York: Harper \& Row, Publishers, 1977), 101-115; Carlo Ginzburg, Ecstasies: Deciphering the Witches Sabbath (Baltimore, MD: Penguin Books, 1991), 1-30.

12 T. S. R. Boase, Ars Moriendi: Death in the Middle Ages (New York: McGraw-Hill Book Company, 1972), 104-06, and on Dante, 54-58; Marcel Tetel, Ronald G. Witt, and Rona Goffen, eds., Life and Death in Fifteenth-Century Florence (Durham: Duke University Press, 1989), 1-15; Philippe Ariès, Images of Man and Death (Cambridge, MA: Harvard University Press, 1985).

${ }^{13}$ Luisa Cogliati Arano, The Medieval Health Handbook: Tacuinum Sanitatis (New York: George Braziller, 1976); John C. Demaray, Dante and the Book of the Cosmos, Transactions of the American Philosophical Society, Vol. 7, part 5 (Philadelphia: American Philosophical Society, 1977); Laurinda Dixon, "Music, Medicine, Morals: The Iconography of an Early Musical Instrument,” Studies in Iconography 7-9 (1981-1982), 147-156.

14 See Guazzo, Malleus Maleficarum, 31.
} 
Christian Church, under the influence of the Dominican friars, wanted to control heresy and persecute witches. The Dominican friars viewed themselves as worshippers of God and theirs enemies as worshippers of the devil. Thus, for the Christian Church, the devil became the Simia Dei, that is, the ape of God or the imitator of God. ${ }^{15}$

Images of evil were recorded in ancient times. For example, the Assyrians and the Babylonians depicted the devil with the head of a lion and the feet of an eagle. ${ }^{16}$ At times, the Egyptians represented the devil as a baboon. Medieval Christian representations of the devil portrayed him as a dragon, a he-goat, a wolf, a cat, an owl, and half-human. The representations of Hell in the Renaissance relied on these literary and visual assimilations as well as on images based on the Bible, Saint Augustine's City of God, Thomas Aquinas' Summa Theologia, the Visio Tundali, and the Malleus Maleficarum. In the fifteenth century, as the Inquisition inspired concerns about the devil, representations of demons increased, evoking further religious and political issues. For example, the devil appeared in fifteenth- and sixteenth-century art and literary works in human disguises such as that of a monk, a learned professor in robes, or a man with claws, horns, and bat wings. The devil was portrayed as a force of evil in the world and ruler of the underworld. The devil consumes the body or the soul of the individual; he demands the individual's life or virtue.

The devil was also associated with the natural elements, such as fire or water. According to the Evangelist Matthew (Book 24) and the Book of Enoch, the devil relates to Hell and fire, deriving from the transformation of fallen angels into devils. Hell and the underworld were created by the rebel angel Lucifer, whose sin of pride caused his fall from Heaven into the abyss of Hell. The linking of Hell to fire comes from the legend of Vulcan, the God of Fire in pagan mythology. The worship of Vulcan and the secret cults of evil powers subsequently became associated with Lucifer and the underworld. Like a pagan god, the devil in Hell rules the underworld; he is the god of Hell. The devil is the instigator of sin and then carries out punishment of the sinner. Obviously Dante incorporated this traditional literary tradition into his Inferno, but his Lucifer resides in the center of an iceberg.

\section{Representations of Hell in Italian Paintings: Last Judgments}

Early representations of Hell can be seen in paintings of Last Judgment scenes (Giotto, Signorelli, Michelangelo). Visions of phantasmic infernos show devils or demons in control: they castigate, torture, and ultimately destroy those who have sinned through superstition and the practice of magic and witchcraft.

Representations of Hell closely relate to depictions of vices, namely, the seven deadly sins (anger, avarice, envy, gluttony, lust, pride, and sloth) and the devil or Simia Dei. Illustrations show Hell to be associated with human beings' combat against vice and eroticism and with the practices of alchemy and witchcraze. The paintings show instruments, devices, and activities of demons; musical instruments; acts of torture; and the transformation of individuals into hybrid forms. Artists who embraced the Church's teachings depicted in their paintings a vision that ran parallel to the Church's call to destroy witchcraft. However, both artists and the Church, through their respective means-pictorial image and literary manifestos, such as the Visio Tundali and the Malleus Maleficarum -inadvertently encouraged and glorified the fantastic qualities of the witchcraze movement.

Last Judgment paintings, then, combine the medieval themes of Dies Irae [the Days of Wrath] with the fantastic elements of the Apocalypse, all seen in a chaotic jungle of fire. The earth is given over to infernal

\footnotetext{
${ }^{15}$ Kelly, The Devil, Demonology and Witchcraft, 53.

16 Alice K. Turner, The History of Hell (New York: Harcourt Brace \& Company, 1993), 5-19.
} 
monsters. The background is replete with horrors, pits, flaming houses, and towers. Hell rushes out angrily, people are burned alive or hanged, millstones of agonies occur, devils fly, water tortures are seen in the depths of the Rivers Erebos and Avernus. Evil is loosed upon earth, and the picture of retribution found in Hell can be seen in the Last Judgment paintings, ${ }^{17}$ such as the twelfth-century mosaic Last Judgment from the Cathedral of Torcello in Venice, likely seen by Dante. In the Hell, mouth can be seen an enthroned Byzantine Satan depicted as a human holding the Antichrist on his lap. Traditionally, Byzantine illustrations of Hell are uncluttered compared to the depiction of Hell in Western art, which represents a chaotic and phantasmal world.

Furthermore, the unveiling of the grand mosaic decoration on the cupola of the Baptistery in Florence in 1300 must have been a noteworthy event. Dante, no doubt, attended the unveiling and subsequently borrowed some of its imagery for executing his own Inferno. The mosaic shows earth infested with the power of evil. The seven deadly sins are again depicted, and the punishment for their perpetrators is described. Further castigation of individual sins spreads not only on their final day—Last Judgment—but also continuously through daily life; life on earth is infernal. Anticipating the later Visio Tundali and the Malleus Maleficarum, the artists describe in these paintings of Hell the powers of Satan or Simia Dei and their manifestations: Satan is the architect, creator, and ruler of the underworld in the same fashion as God is the designer of the world. Satan is the Simia Dei as described in Malleus Maleficarum:

As divine wisdom permits certain evil to be done by bad Angels or individuals, for the sake of the good that God draws therefrom, so also the good Angels do not altogether prevent wicked men or devils from doing evil. ${ }^{18}$

In the Italian Renaissance, the enthusiastic reappearance of Dante's poema sacro provided a paradox: on one hand, the Inferno expanded the sentiment of witchcraze and individual damnation; on the other hand, Purgatorio and Paradiso offered forgiveness and salvation for humankind (Figure 1).

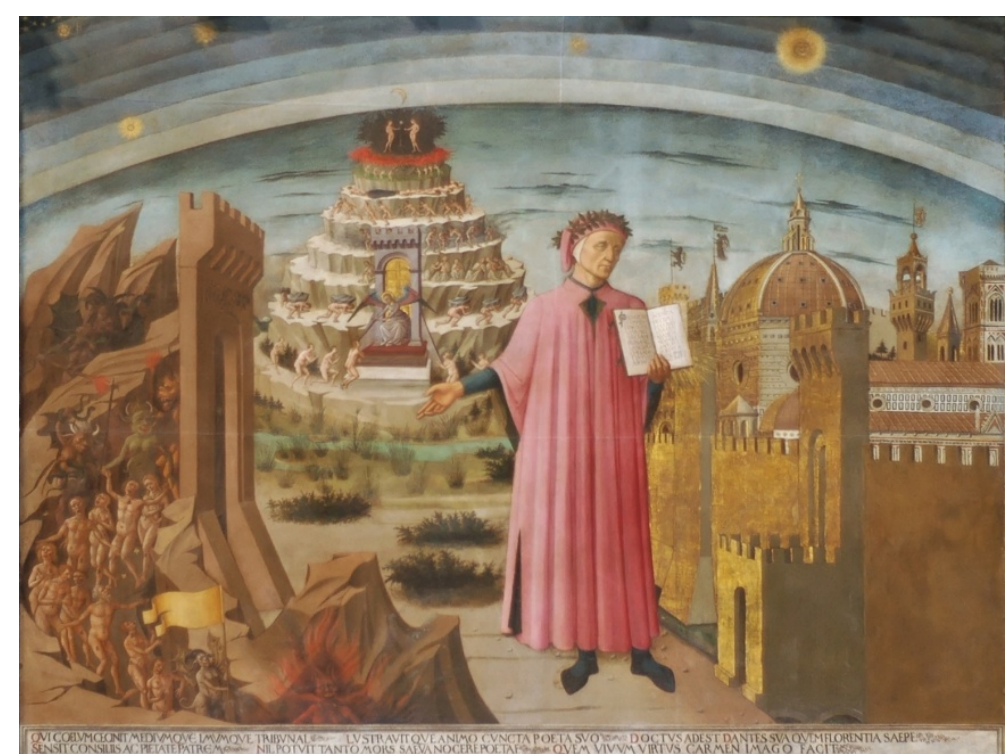

Figure 1. Domenico di Michelino, Dante and his Poem, 1465. Santa Maria del Fiore (Duomo), Florence. Photo: Public Domain. Wikimedia.org.

\footnotetext{
17 See Richard Cavendish, Visions of Heaven and Hell (London: Orbis Publishing, 1977); Turner, The History of Hell; and Nassar, Illustrations to Dante's Inferno, for numerous illustrations on this theme.

${ }^{18}$ See Guazzo, Malleus Maleficarum, 111.
} 
After Dante's banishment from Florence in 1302 for political reasons, he visited Giotto in Padua, where the painter was working on his famous frescoes for the Scrovegni family, the so-called Arena Chapel. It is assumed that both poet and painter spent a great deal of time conversing about artistic images, for in the Last Judgment, Giotto appropriated the image of a hideous devil, in the form of a large demon both devouring and excreting sinners, from Dante's poema sacro concept of Satan as well as the variety of punishments administered to the sinners in Hell (Figure 2).

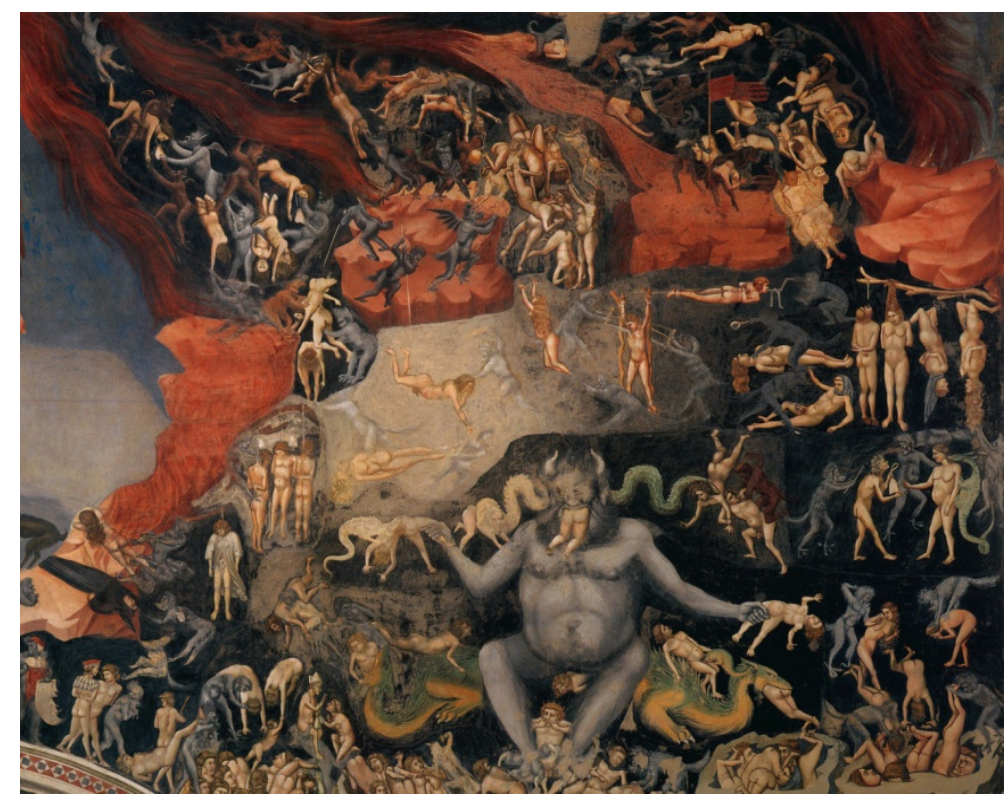

Figure 2. Giotto, Last Judgment, det. Hell, 1305. Arena Chapel, Padua. Photo: Public Domain. Wikipedia.org.

In the Trecento and Quattrocento (fourteenth and fifteenth centuries), several artists absorbed Dante's vision of Hell in their own depictions of the Last Judgment theme. They did so with zest, magnificent details, and sardonic humor. Among these are Francesco Traini's Last Judgment at the Camposanto in Pisa of the 1340s, Orcagna or Nardo di Cione's Last Judgment in the Strozzi Chapel of Santa Maria Novella in Florence of 1350; Fra Angelico's Last Judgment in San Marco, Florence of 1430s, and Giovanni di Paolo's Hell in the Pinacoteca of Siena of $1453 .^{19}$

In the sixteenth century, in a less hallucinatory manner, Signorelli's Last Judgment for the Orvieto Cathedral of 1503 and Michelangelo's Last Judgment in the Sistine Chapel of 1541 both allude to Dante's entrance to Hell (Figure 3). In both frescoes, Charon ferries the damned across the River Acheron to be judged on the other shore by Minos. In Michelangelo's image, Charon whacks the sinners with his oar just as Dante describes, while Minos, both in Signorelli's and Michelangelo's works, winds his tail around his body to designate the given sinner's place in Hell, again according to Dante's description. It is known that Michelangelo studied Signorelli's frescoes at Orvieto and that both frescoes are the products of their life-long devotion to Dante and his Divine Comedy. Michelangelo expressed his fascination with Dante, especially in his conversations, in his prose and poetry, and in his alleged complete series of drawings to the poema sacro, lost at sea. Both artists depicted a profound Dantean sense of the human condition in these powerful rhythms of

\footnotetext{
${ }^{19}$ Giovanni di Paolo also illuminated the Paradiso from Dante's Divine Comedy. See John Pope-Hennessy, Paradiso: The Illuminations of Dante's Divine Comedy by Giovanni di Paolo (New York: Random House, 1993).
} 
dramatic action and gesture. The tonalities of the Dantean text, the complexity, compassion, the faith and the doubt, the sardonic comedy and the poignant tragedy have never been so awesomely caught in these masterful Last Judgment paintings. ${ }^{20}$

Impelled by Michelangelo's Last Judgment, other Cinquecento painters also represented this theme. ${ }^{21}$ For example, in the 1530s, Jacopo da Pontormo (1494-1557) made drawings of a Last Judgment for the Medicean church of San Lorenzo, ${ }^{22}$ and in 1566 Giorgio Vasari (1511-74) executed drawings of a Last Judgment for the main altarpiece of the Santa Croce at Boscomarengo. In 1572, with the advice of the humanist Vincenzo Borghini (1515-1580), Vasari initiated a complex iconographical program of yet another Last Judgment, a decoration inside the dome of the Cathedral of Florence. Years later it was completed by one of his assistants, Federico Zuccaro. ${ }^{23}$

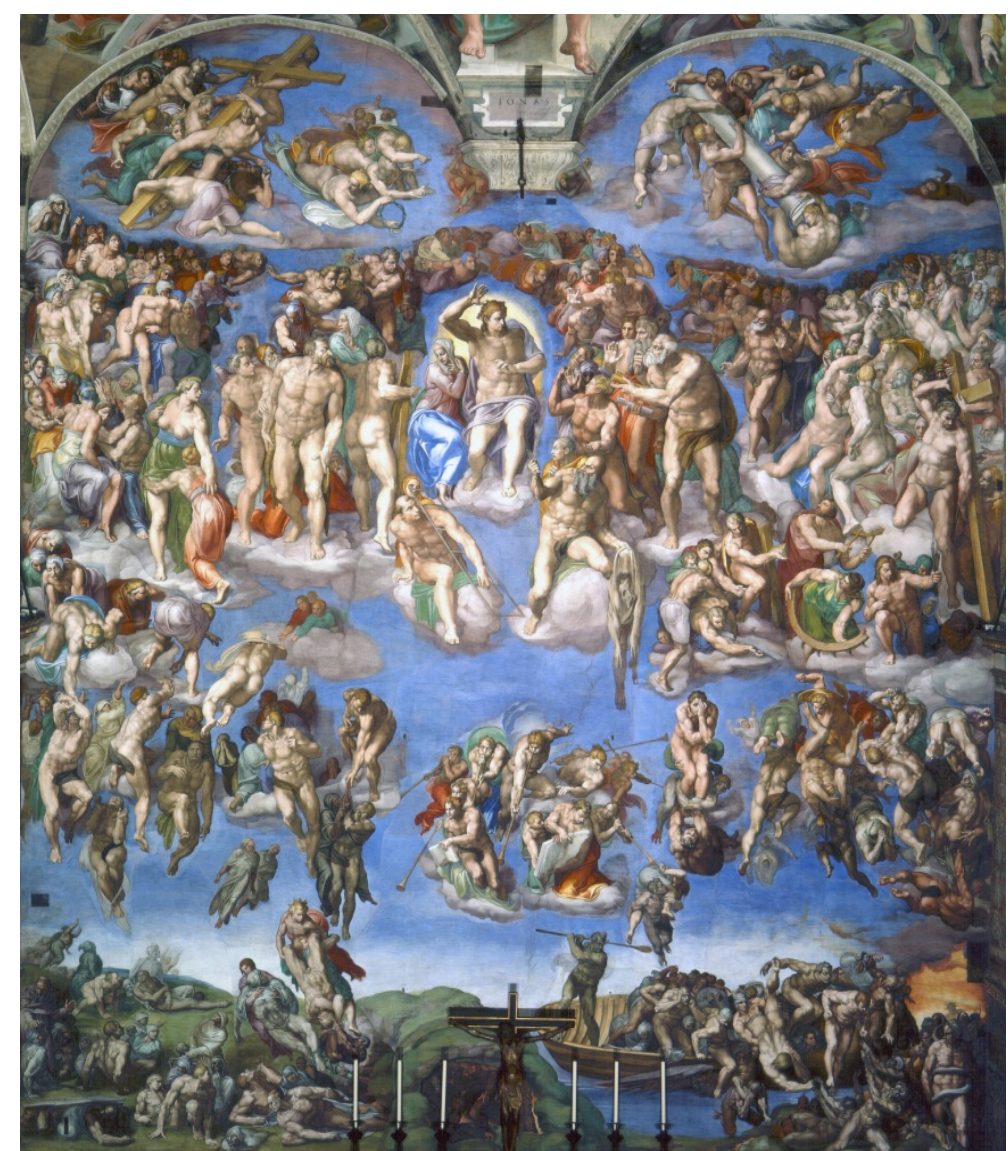

Figure 3. Michelangelo, Last Judgment, 1541, Sistine Chapel, Vatican. Photo: Public Domain. Wikepedia.org.

\section{Drawing Illustrations for Dante's Divine Comedy: Inferno}

It is easy to understand why people of the sixteenth century were moved by Dante's commedia by reading

\footnotetext{
${ }^{20}$ Turner, The History of Hell, 114-125; Corrado Gizzi, Signorelli e Dante (Milan: Electa, 1991); Nassar, Illustrations to Dante’s Inferno, passim.

${ }^{21}$ See Paul Barolsky, “The Visionary Art of Michelangelo in the Light of Dante,” in Dante Studies 114 (1996), 1-14; and Jean-Pierre Barricelli, “Dante’s Inferno I in the Visual Arts,” in Dante Studies 114 (1996), 14-39.

${ }^{22}$ David J. Cast, ed., The Ashgate Research Companion to Giorgio Vasari (Burlington: VT: Ashgate, 2016), 31; and Elizabeth Pilliod, Pontormo, Bronzino and Allori: A Genealogy of Florentine Art (London: Yale University Press, 2001), 266.

${ }^{23}$ Cristina Acidini Luchinat, "Vasari’s Last Paintings: The Cupola of Florence Cathedral,” in Philip Jacks, ed., Vasari’s Florence: Artists and Literati at the Medicean Court (Cambridge: Cambridge University Press, 1998), 238-250; and Julian Brooks, Taddeo ad Federico Zuccaro: Artist-Brothers in Renaissance Rome (Los Angeles: The J. Paul Getty Museum, 2007).
} 
Michele Barbi's Della fortuna di Dante nel secolo XVI and Cesare Balbo's Vita di Dante. These authors explained well the great literary revival of Dante's writings in the 1540s, in terms of purity, clarity, and concise usage of the Tuscan language, which they viewed as superior to Latin or Greek in expressing the sentiments and conceit of humankind. ${ }^{24}$ Obviously, the literary exhilaration for and diffusion of Dante's poema sacro inspired the great masters of the Cinquecento (sixteenth century), including Michelangelo. ${ }^{25}$

The illustrations of the poema sacro in the Quattrocento and Cinquecento reveal artists' fascination in visualizing Dante's poetical imagery. In Renaissance Florence, the enthusiastic reappearance of Dante's poema sacro by Cristoforo Landino’s Commentary on the Divine Comedy in 1481 provided artists with a new creative impetus for illustrating Divine Comedy with drawings.

Botticelli designed two sets of drawings to illustrate Dante's Divine Comedy, as mentioned earlier. The first set accompanied Landino's Commentary on Dante's Divine Comedy in 1481, while the second set was commissioned by Lorenzo Pierfrancesco de' Medici in 1482. The first version contains nineteen drawings, mostly illustrating the Inferno, while the second version illustrates the complete text of the Divine Comedy. ${ }^{26}$ Botticelli's illustration for the poema sacro received high praise both in his own time by Giorgio Vasari and in subsequent centuries by, for example, the Queen of Sweden. ${ }^{27}$

Since their discovery in the late nineteenth century, Botticelli’s drawings for Dante's Divine Comedy have been recognized as central to his artistic achievement. His drawings were intended to be part of a sumptuous illuminated codex of the poema sacro. The volume's design would have been unprecedented: it would have opened vertically, with each turn of the page offering the complete text of a canto beneath a full-page illumination showing that canto's entire narrative sequence. There is balance between the compositional arrangements of the illustrations with the respective text, that is, the image and the word are bonded to give meaning and reveal the tragedy of humanity. This commission was Botticelli's most ambitious artistic endeavor. Unfortunately, he never completed the project. Many of the drawings are not fully fixed in pen, and on only four of the extant ninety-two drawings is there illumination. The frontispiece is fully colored (Figure 4).

\footnotetext{
${ }^{24}$ Michele Barbi stated: “A gli academi Fiorentini la Divina Commedia serviva a pennello per dimostate che la lingua Toscana era alta ad esprimere qualsi voglia contalto di filosofia o astrologia o di qual unque altra sicenza e cosi bene come fosse la latina e forse la Greca. Lo studio e il commento del poema fu perció tenuto in gran conto, sia per la purezza e la proprietà della lingua, sia per l'altezza e l'importanza della materia trattata" [To the Florentine Academician the Divine Comedy fit well in demonstrating that the Tuscan language was superior and even more in expressing thoughts regarding philosophy, astrology, or any other science, like was Latin or Greek. The study and the comments on the poem were highly esteemed because of the purity and accuracy of the language as well as for the high level and significance of the subject discussed] (Della fortuna di Dante nel secolo XVI (Pisa: T. Nistri and Co., 1890), xii). Cesare Balbo too commented: "il Cinquecento fu per Dante un secolo di gloria crescente e diffondesi” [the Cinquecento was for Dante a century of increasing glory and diffusion] (Vita di Dante (Turin, 1856, repr. Florence: Sansoni, 1966), 437).

${ }^{25}$ In Bologna, Michelangelo read in Casa Aldobrandi the poema sacro, and in 1519, when the Academia Medicea sent Leo X il noto memoriale requesting that Dante's remains be transferred from Ravenna to Florence, Michelangelo composed a famous poem in honor of this event: "Io Michelangelo scultore, il medesimo a vostra Santità, supplico ofrendomi al divin poeta fara la sepoltura sua, conducente e in loco onerevole in questa città" [I Michelangelo sculptor, the same one to His Holiness, beg that the divine poet be buried accordingly and in a honorable place in this city]. See Corrado Ricci, Ultimo Rifugio di Dante Alighieri con illustrazioni $e$ documenti [The Last Refuge of Dante Alighieri with illustrations and documents] (Milan: U. Hoepli, 1891), xiii and 337.

${ }^{26}$ The first edition is in the Biblioteca Ricciardiana in Florence. The most complete version of the second edition is at the Kupferstichkabinett, Staatliche Museen in Berlin.

27 Watts, "Pictorial Wit and Parody as Narrative Tools."
} 


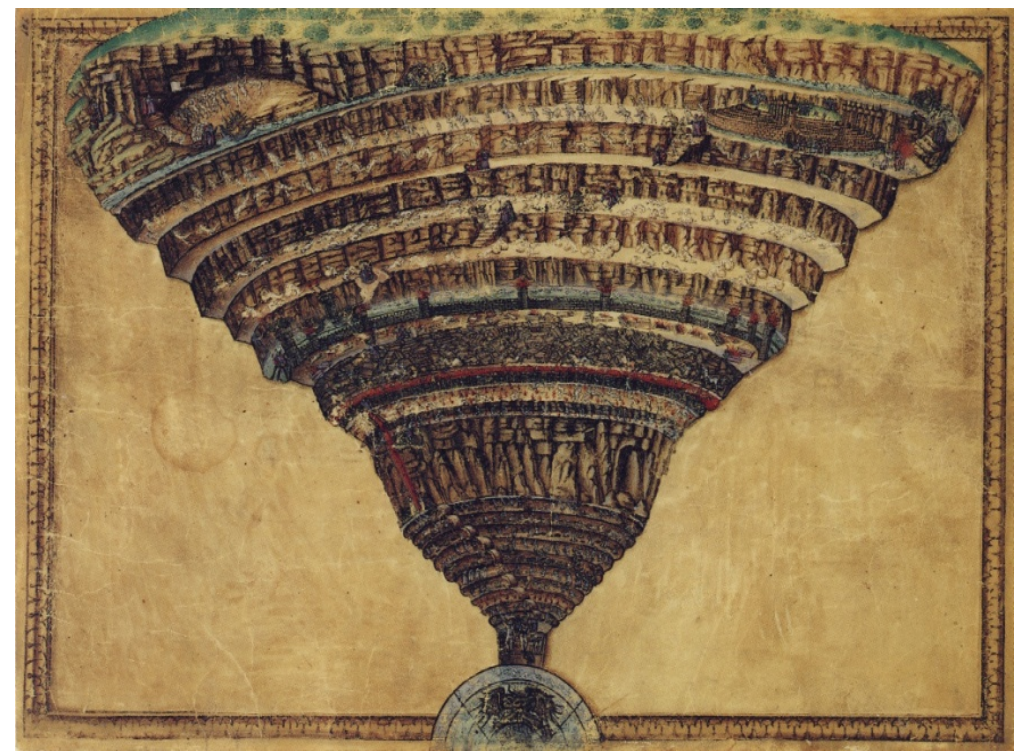

Figure 4. Sandro Botticelli, Chart of Hell, 1482-90. Frontispiece for Dante’s Divine Comedy. Biblioteca Apostolica Vaticana, Vatican. Photo: Public Domain. Wikepedia.org.

Although Botticelli's illustrations for the poema sacro have long been praised for their beauty and or their fidelity to the text, those for the Inferno have been widely faulted for failing to evoke the horrors of the damned and Hell's wretched desolation. As early as 1896, Bernard Berenson asserted that the beauty and delicacy of Botticelli's line undermined the Inferno's content and that as illustrations his drawings were ineffectual. ${ }^{28}$ Echoing Berenson, Herbert Horne found the demons "grotesque, absurd, and frightening only in their ugliness.”29 Barbara Watts contended that such criticism greatly underestimates the extent of Botticelli's understanding of the text and the subtleties of his pictorial treatment. For Watts, Botticelli was a Dantista who, through his illustrations, sought to convey the many levels of the Divine Comedy's richness and complexity. ${ }^{30}$ To see this, however, "one must look beyond the literal fidelity of his narrative treatment and beyond the beauty of his designs but focus on the pictorial parody which Botticelli inventively used to convey the spirit, style, and significance of Dante’s verse.”31

In writing the Divine Comedy, Dante assumed that his readers would bring to the poem an extensive body of literary knowledge. Thus his poema sacro contains numerous metaphors, allegories, and literary conceits that only the literati would recognize. Botticelli likewise assumed an artistic sophistication on the part of his audience to provide a pictorial tapestry in which the Divine Comedy is woven. Correctly so, for Botticelli's patron Lorenzo Pierfrancesco de' Medici, who spent his youth in the Medici Palace and who commissioned the Primavera and the Birth of Venus, was artistically erudite and would have understood the significance of his pictorial conceits. $^{32}$

Botticelli's illustrations reveal a strong individual quality of design. The compositions for the Inferno show inventive architectural settings, medieval towers, boats, and devils-the voyage into chaos as seen in

\footnotetext{
${ }^{28}$ Bernard Berenson, “Botticelli’s Illustrations to the Divina Commedia,” The Nation (Florence, October 22, 1896), 363.

${ }^{29}$ Herbert Horne, Botticelli, Painter of Florence (Princeton: Princeton University Press, 1987), 207.

30 See Watts, "Sandro Botticelli's Illustrations for Inferno VIII and IX”, 149-173.

31 Ibid., 149-173.

32 Liana De Girolami Cheney, Botticelli’s Neoplatonic Images (Potomac, MD: Scriptura Humanistica, 1993), 27-43, for a discussion on Renaissance Neoplatonism.
} 
Canto IX, The City of Dis. The drawings for the Purgatorio are embellished with depictions of Florentine pageantry and landscape scenes as seen in Canto XXX, Beatrice. And the illustrations for the Paradiso express in a lyrical visual imagery an interpretation of contemporary philosophy, that is, Renaissance Neoplatonism: redemption through the Christian faith, as illustrated in Canto XXVI, the Fixed Star. ${ }^{33}$

Botticelli's illustrations for the Inferno depict Dante's account of his journey through Hell in a manner that underscores its deeper meaning: a visual and iconographic parody. As Eric Auerbach and Barbara Watts have observed, Dante conveys Hell's perversions or earthly perversions with "figural inversions," one of which is the use of iconographic parody. ${ }^{34}$ According to Watts, in using parody to convey the significance of Dante's narrative, Botticelli appropriated the poet's methods and thereby transformed his task from illustration of the Inferno to the making of its pictorial complement—an ut pictura poesis [as is painting, so is poetry]. ${ }^{35}$ In doing so, Botticelli's illustrations clearly demonstrate a deep understanding of and a dramatic response to the Inferno and its complex symbolism. ${ }^{36}$

A century after Botticelli commenced his series of drawings for the poema sacro, two artists in Florence-Hans van der Straet, also called Stradanus or Stradano, and Frederico Zuccaro-were preparing their own series between 1585 and 1588. ${ }^{37}$ Like Botticelli's, their series remained unpublished and largely unstudied until the late nineteenth century.

In the Florentine Cinquecento, a revived interest in Dante's Divine Comedy was fostered by a series of open lectures on Dante presented by Francesco Verini il Vecchio and Pier Francesco Giambullari in Santa Maria Novella during the 1540 s. $^{38}$ Furthermore, Duke Cosimo I, as a patron of the arts, established a lecture series on Dante's poema sacro. Records reveal that Cinquecento Florentine artists were deeply touched by the poet: Agnolo Bronzino (1503-1572) recited by heart the Divine Comedy; Michelangelo owned a copy of Landino's commentary and quoted the poet in his sonnets as well as depicted it in his paintings; the humanist Benedetto Varchi (1503-1565) owned a copy and made notations on Dante's Commedia; and Vasari too owned a copy of the poema sacro and, inspired by its verses, illustrated several allegorical images for the wedding decorations of Francesco de’Medici and Giovanna of Austria. ${ }^{39}$ His assistants Stradano and Zuccaro, following in Vasari's footsteps by owning copies of Dante's Divine Comedy, went even further. Each beautifully illustrated his own version of the Commedia.

Zuccaro's drawings for the Divine Comedy are presently in the Gabinetto dei Disegni e delle Stampe in the Galleria degli Uffizi in Florence, and those of Stradano are in the Biblioteca Laurenziana in Florence. ${ }^{40}$ Both artists evoke an elegiac mood of the pathos of Hell and of the sinner's suffering, which seems both a personal

\footnotetext{
33 Ibid.

34 Watts, "Pictorial Wit and Parody as Narrative Tools"; and Eric Auerbach, "Figure," in his Mimesis: The Representation of Reality in Western Literature, trans. W. R. Trask (Princeton: Princeton University Press, 1974), 174-202.

35 See Auerbach, "Figure," in his Mimesis, 174-202.

${ }^{36}$ Liana De Girolami Cheney, “I Disegni di Botticelli per La Divina Commedia di Dante,” in Letteratura Italiana e Arti Figurative (Florence: Leo S. Olschki, 1987), 1-8.

37 See Gizzi, ed., Giovanni Stradano e Dante, 13-63.

38 See Barbi, Della Fortuna di Dante nel Secolo XVI, 184.

39 See Cast, The Ashgate Companion to Giorgio Vasari, 329-320; and Conti Ginori, ed., L'apparato per le nozze di Francesco de' Medici e di Giovanna d'Austria: nelle narrazioni del tempo e da lettere inedited di Vincenzo Borghini e Giorgio Vasari illustrato con disegni originali (Florence: L. S. Olschki, 1936).

${ }^{40}$ Gizzi, Federico Zuccari e Dante, 159-160; Michael Brunner, "Storia del 'Dante historiato da Federico Zuccaro,’” in Gizzi, Federico Zuccari e Dante, 71-74; Anna Lenzoni, "La Biblioteca Medicea Laurenziana e il Codice Mediceo Palatino,” in Gizzi, Giovanni Stradano e Dante, 211-222; and Michael Brunner, "Alcune note sulla commissione dei disegni danteschi di Giovanni Stradano," in Gizzi, Giovanni Stradano e Dante, 123-132.
} 
expression and true to an aspect of Dante's tonality. Zuccaro and Stradano reveal Dante's Inferno with parody, that is, the illustrations can be seen as grotesque, burlesque, and mannered expressions and portrayals of life.

Vasari highly praised Stradano's illustrations on Dante’s Divine Comedy for having good design and capriciousness with great conceits (buon disegno, bonissimi capricci, molta invezione). ${ }^{41}$ According to $\mathrm{J}$. Addington Symonds and Guido Biagi, compilers of Stradano's drawings, the origin and history of this commission are unclear. ${ }^{42}$

They speculate that Stradano might have responded to a request from the Accademia degli Alterati, based on the fact that Stradano, in his diary, Rinnovellato, makes reference to a Laurentian codex (Figures 5a and 5b).

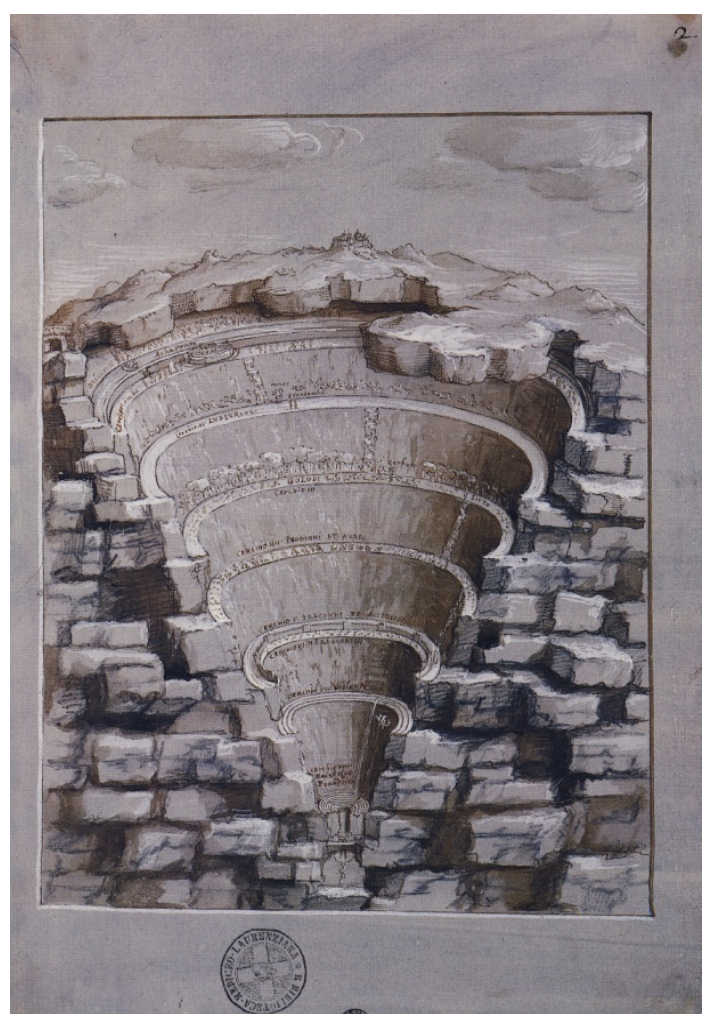

Figure 5a. Giovanni Stradano, Chart of Hell, 1588, for Dante’s Divine Comedy. Photo: Public Domain. Wikipedia.org. Courtesy of the Biblioteca Laurenziana, Florence.

\footnotetext{
${ }^{41}$ Giorgio Vasari, Le vite dei più eccellenti pittori, scultori ed architettori [The lives of the most excellent painters, sculptors and architects], ed. Gaetano Milanesi, Vol. 9 (Florence: G.S. Sansoni, 1906, repr. 1973 of Giunti, 1568), 5: 396.

${ }^{42}$ Dante's Illustration for the Divine Comedy, executed by J. Stradanus, 1587, and reproduced in phototype from the originals in the Laurentian Library of Florence; with an introduction by G. Biagi and a preface by J. A. Symonds (London: Edwards, 1892); Guido Biagi, Le illustrazioni alla Divina Commedia di Giovanni Stradano 1587 (Florence: Fratelli Alinari, 1892 and 1893 editions); Corrado Ricci, La Divina Commedia di Dante Alighieri nell'arte del Cinquecento (Rome: Fratelli Treves Editori, 1908).
} 


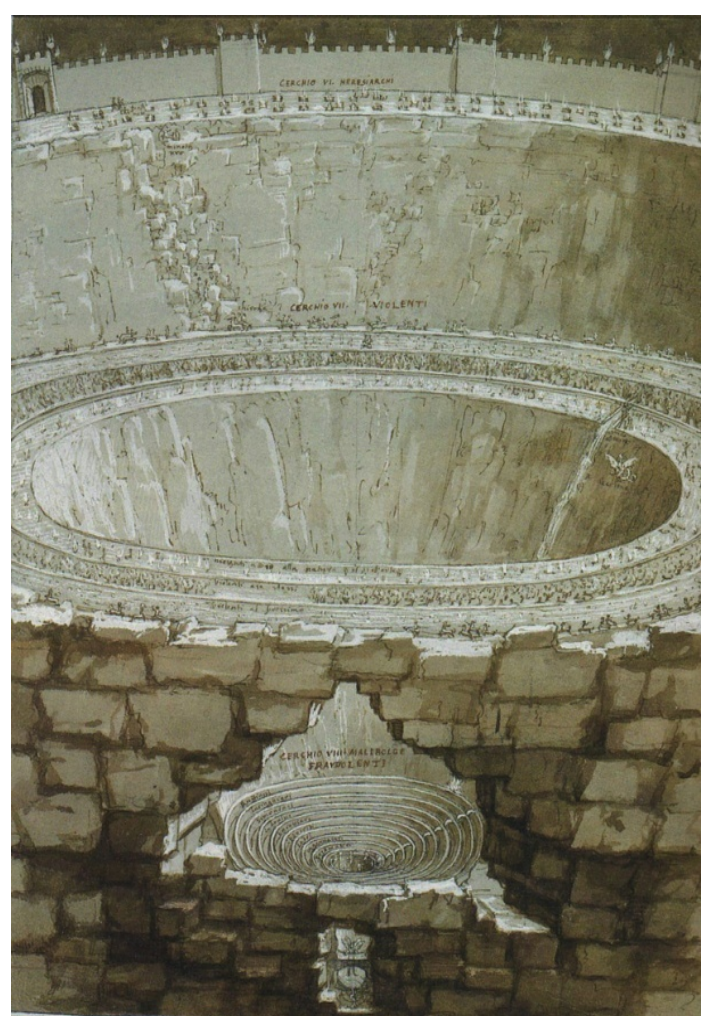

Figure 5b. Giovanni Stradano, Chart of Hell, 1588, for Dante’s Divine Comedy. Photo: Public Domain. Wikepedia.org. Courtesy of the Biblioteca Laurenziana, Florence.

Stradano's pen-and-ink drawings reflect a grey and green tonality with watercolor touch-ups of white highlights. The composition of the illustrated text consists of twenty-eight drawings: twenty-four of the Inferno, and four of Purgatorio, signed Jo. Stradanus, Flanders, inventor Florentiae 1587-1588. ${ }^{43}$ Unlike Botticelli and Zuccaro, Stradano emphasized in his drawings the most pregnant moment of Dante's cantos, moving away from the decorative aspect and stage setting for the narrative to concentrate on the psychological impact of the scene. In Botticelli's illustrations, the viewer observes with fascination the unfolding of the drama; in Stradano's illustrations, the viewer experiences with empathy the outcome and suffering of the protagonists; whereas in Zuccaro's illustrations, the viewer is instructed and reminded of Dante's masterful text.

Zuccaro illustrated Dante's poema sacro during his Spanish sojourn at the Escorial in 1585-1588. ${ }^{44}$ The inventories of the Escorial Library demonstrate that the library at this time contained several editions of and commentaries on Dante's Divine Comedy, including the richly decorated and annotated edition of the Florentine Francesco Sansovino entitled Dante con l'esposizione di Cristoforo Landino, et di Alessandro Velutello, sopra la sua Commedia dell'Inferno, del Purgatorio, et del Paradiso published by the Giovanbattista, Marchiò Sessa, a Venetian printing press, in 1564. Thus Sansovino's edition incorporated the previous commentaries of Cristoforo Landino and Alessandro Vellutello. It is certain that Zuccaro consulted this edition, as well as Rovillio's, during his Spanish visit because, in illustrating Dante's text, he adhered to the descriptions of the Cinquecento Dante's commentators and not Dante's original text.

\footnotetext{
${ }^{43}$ Ludwig Volkmann, Bildich darstellungen zu Dante’s Divina Commedia, bis zu ausgang der Renaissance (Leipzig: n.p., 1892), repr. as Ludwig Volkmann, Iconografia dantesca; The Pictorial Representations to Dante's Divine Comedy, ed. and trans. Charles Sarolea (London: H. Grevel \& Co., 1899).

${ }^{44}$ See Gizzi, Federico Zuccari e Dante, 71-74.
} 
Only 88 drawings designed by Zuccaro for Dante’s Divine Comedy have survived. This includes a colored drawing of a crowned with laurel Dante, seated on a rock and holding his poema (Figure 6). ${ }^{45}$ Perhaps this drawing was used as the frontispiece. Zuccaro's drawings for the Inferno are executed in red and black pencil, the Purgatorio's with pen and bistro, and the Paradiso's with red pencil only.

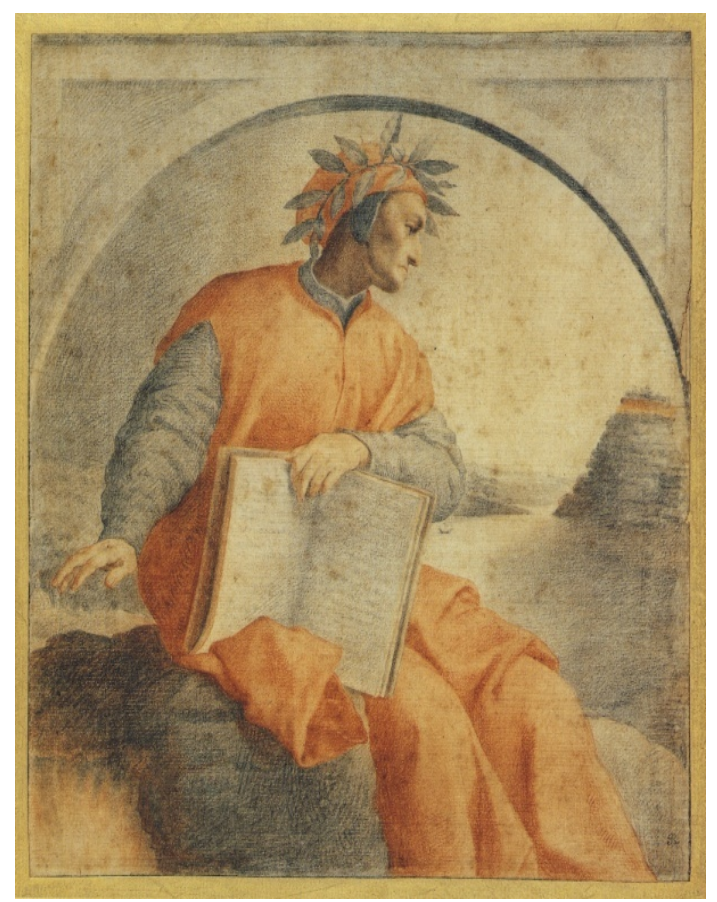

Figure 6. Federico Zuccaro, Dante, 1585, for Dante’s Divine Comedy. Photo Courtesy of the Gabinetto dei Disegni e delle Stampe della Galleria degli Uffizi, Florence.

Stradano's drawing for Dante’s Canto I ${ }^{46}$-Dark Forest—shows Dante waking up in the Dark Forest, where three ferocious animals confront him: the leopard represents malice and fraud; the lion represents violence and ambition; and the she-wolf represents incontinence. Stradano's drawing focused on Dante's somber mood and fear, whereas Botticelli's stressed the intricacy of the Dark Forest. Zuccaro's drawing of Canto I also skillfully portrayed Dante waking up in the Dark Forest confronted by three ferocious animals, as in Botticelli’s drawing (Figures 7, 8, 9).

\footnotetext{
${ }^{45}$ See Gizzi, Federico Zuccari e Dante, 160; and Brunner, “Storia del 'Dante historiato da Federico Zuccaro', 74, nn. 24 and 30. There are several drawings of Zuccaro's Dante, including one at the Uffizi (MS 113) and another at the Fitzwilliam Museum in Cambridge (In. 1176). Zuccaro's inspiration for the representation of a seated Dante, holding his book and looking at the visualization of Hell, was probably from an oil painting of Bronzino's Portrait of Dante of 1530 at the Galleria degli Uffizi in Florence.

46 See Letterio Cassata, “Canto I: The Hard Begin,” in Mandelbaum, et al., Inferno: A Canto-by-Canto Commentary, 9-24.
} 


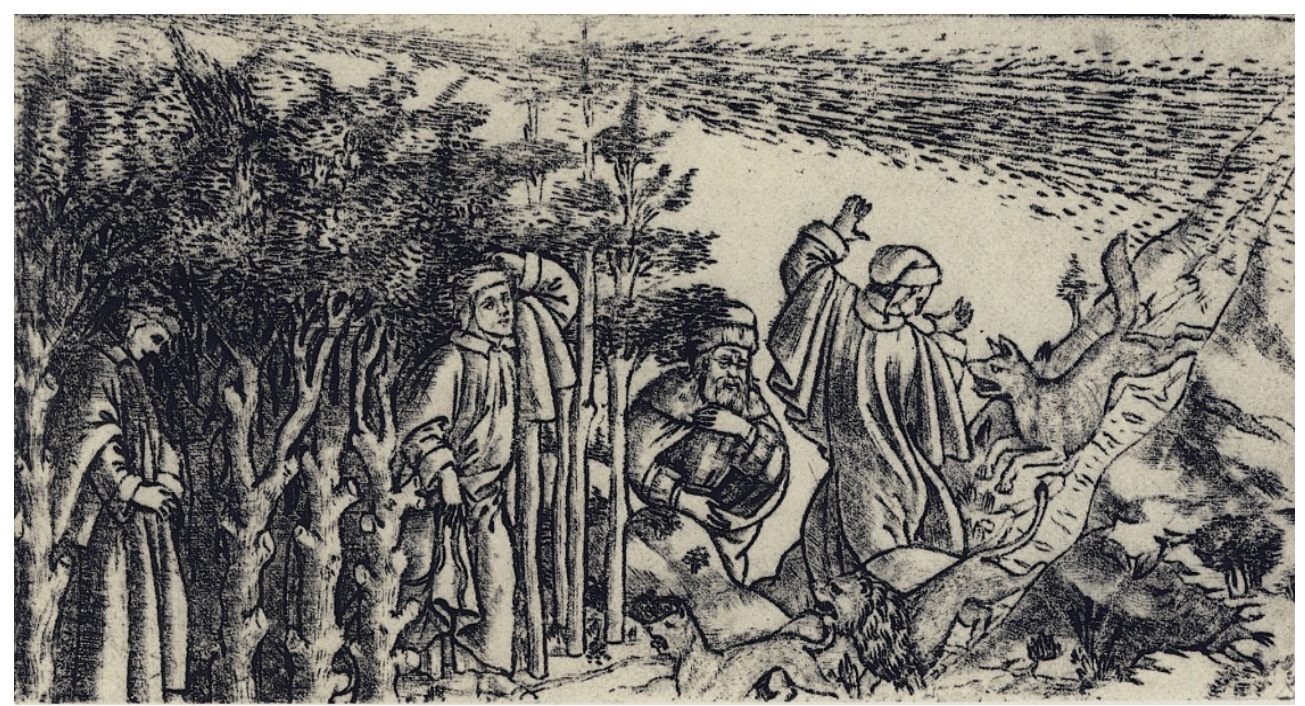

Figure 7. Baccio Baldini’s engraving after Sandro Botticelli, Inferno, Canto 1, Dark Forest, 1481, for the first edition of Dante’s Divine Comedy. Public Domain. Wikepeida.org. Courtesy of Biblioteca Riccardiana, Florence.

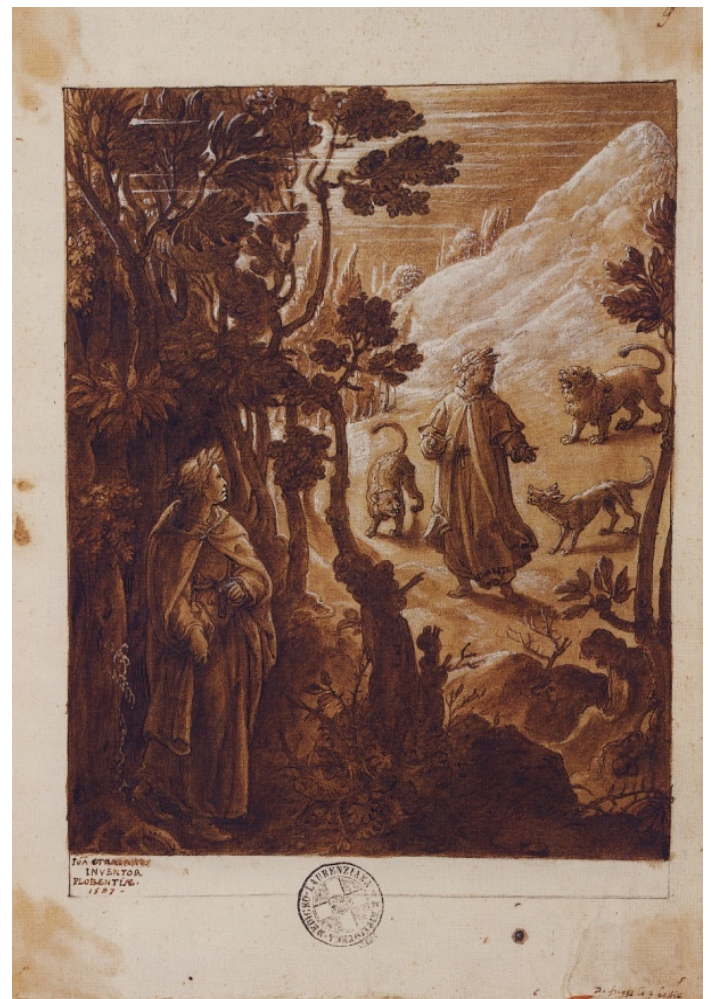

Figure 8. Giovanni Stradano, Inferno, Canto I, Dark Forest, 1588, for Dante’s Divine Comedy. Photo: Public Domain. Wikemedia.org. Courtesy of the Biblioteca Laurenziana, Florence. 


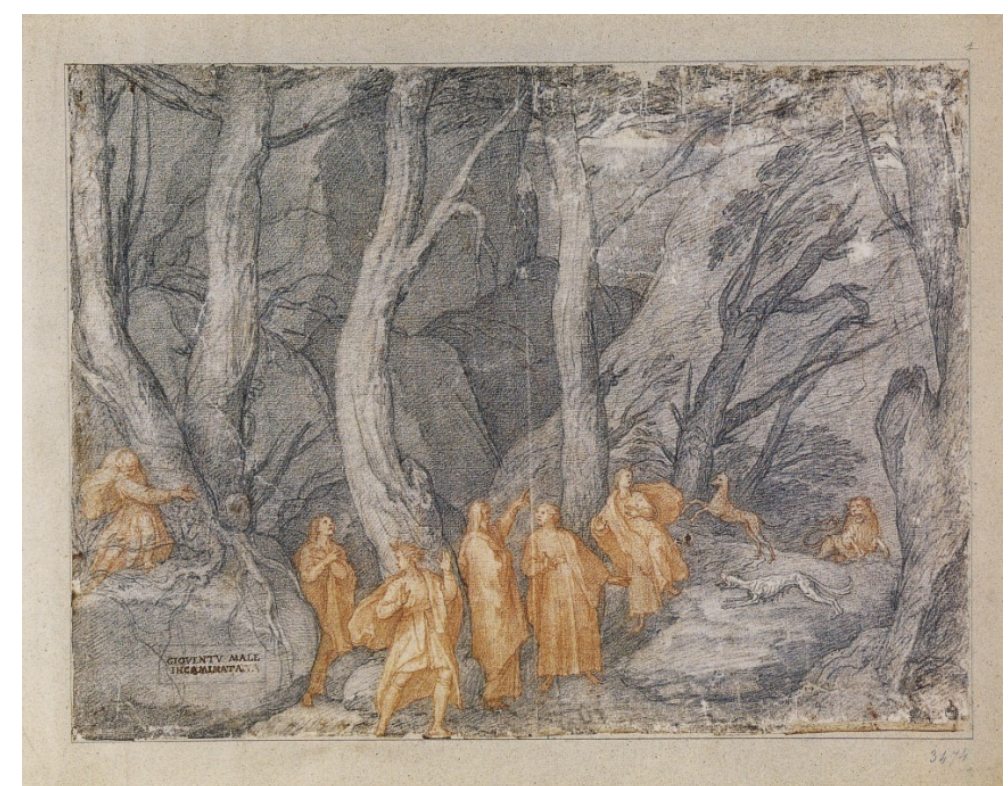

Figure 9. Federico Zuccaro, Inferno, Canto 1, Dark Forest, 1585, for Dante’s Divine Comedy. Photo Courtesy of the Gabinetto dei Disegni e delle Stampe della Galleria degli Uffizi, Florence.

Stradano did not illustrate Dante's Canto III, The Vestibule of Hell. However, both Botticelli and Zuccaro provided an inventive image that incorporates portions of Dante's text (Figures 10, 11, 12). In Botticelli’s first version, only the words Per me [Through me] are visible in the gateway. In contrast, Zuccaro represented an elaborate and extravagant doorway where the poets cross to encounter above them the famous Dantesque quotation:

Per me si va nella città dolente,

Per me si va ne l'etterno dolore,

Per me si va tra la perduta gente.

Giustizia mosse il mio alto fattore:

Fecemi la Divina Potestate,

La somma sapienza e'l primo amore.

Dinanzi a me no fuor cose create

Se non etterne, e io etterno duro.

Lasciate ogni speranza, voi ch'intrate.

[Through me the way to the city of woe,

Through me the way to eternal pain,

Through me the way among the lost.

Justice moved my maker on high:

Divine power made me,

Wisdom supreme, and primal love.

Before me nothing was but things eternal,

And I endure eternally.

Abandon all hope, Ye who enter here.] ${ }^{47}$

\footnotetext{
${ }^{47}$ See Eugenio N. Frongia, “Canto III: The Gate of Hell,” in Mandelbaum, et al., Inferno: A Canto-by-Canto Commentary, 36-49.
} 


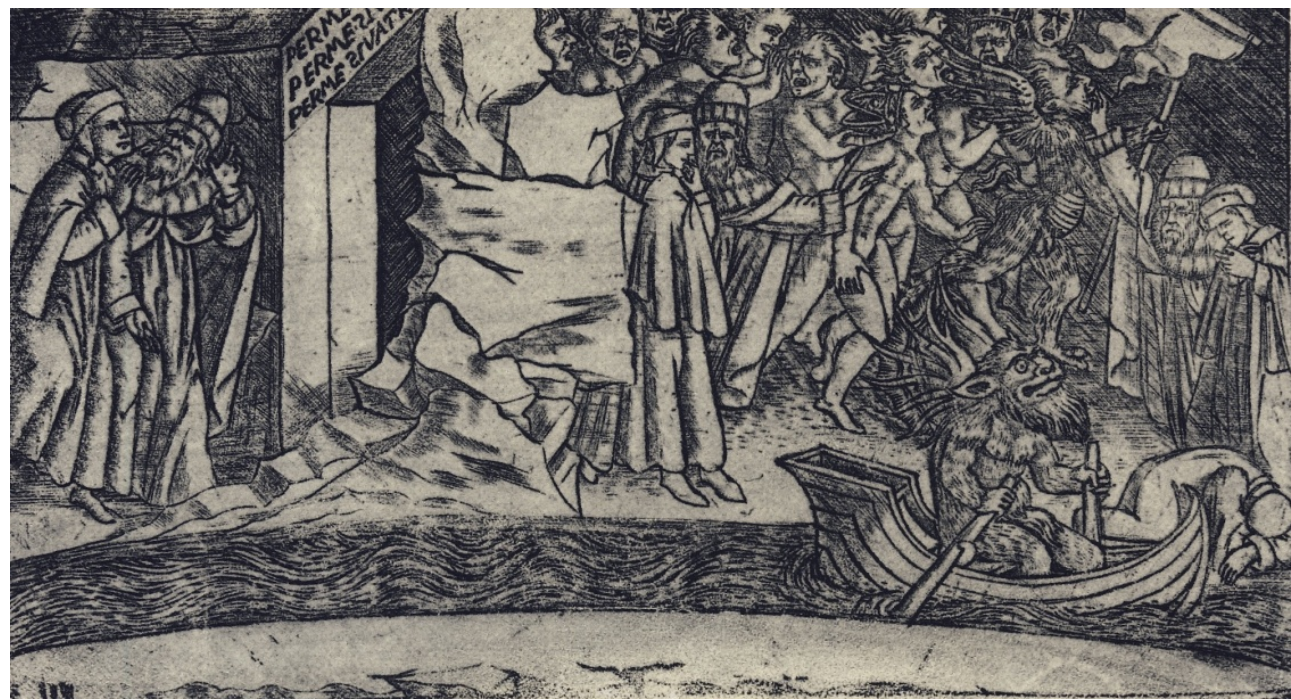

Figure 10. Baccio Baldini's engraving after Sandro Botticelli, Inferno, Canto II1, At the Gate, 1481, for the first edition of Dante's Divine Comedy. Photo: Public Domain. Wikiwand.com. Courtesy of Biblioteca Riccardiana, Florence.

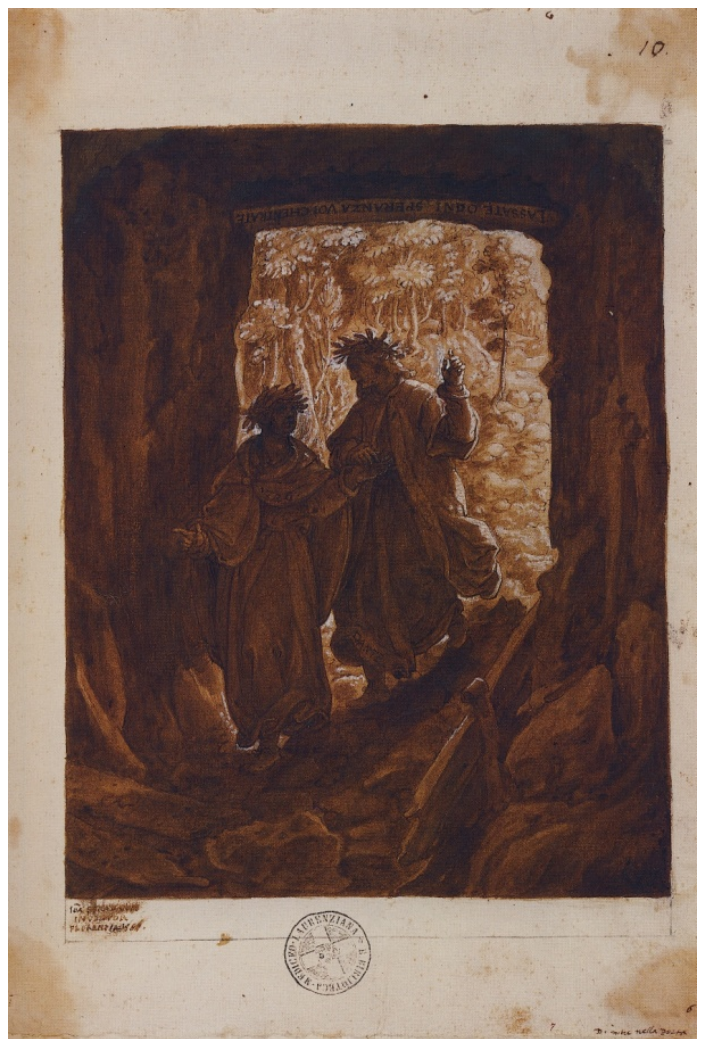

Figure 11. Giovanni Stradano, Inferno, Canto III, At the Gate 1588, for Dante’s Divine Comedy. Photo: Public Domain. Wikemedia.org. Courtesy of the Biblioteca Laurenziana, Florence. 


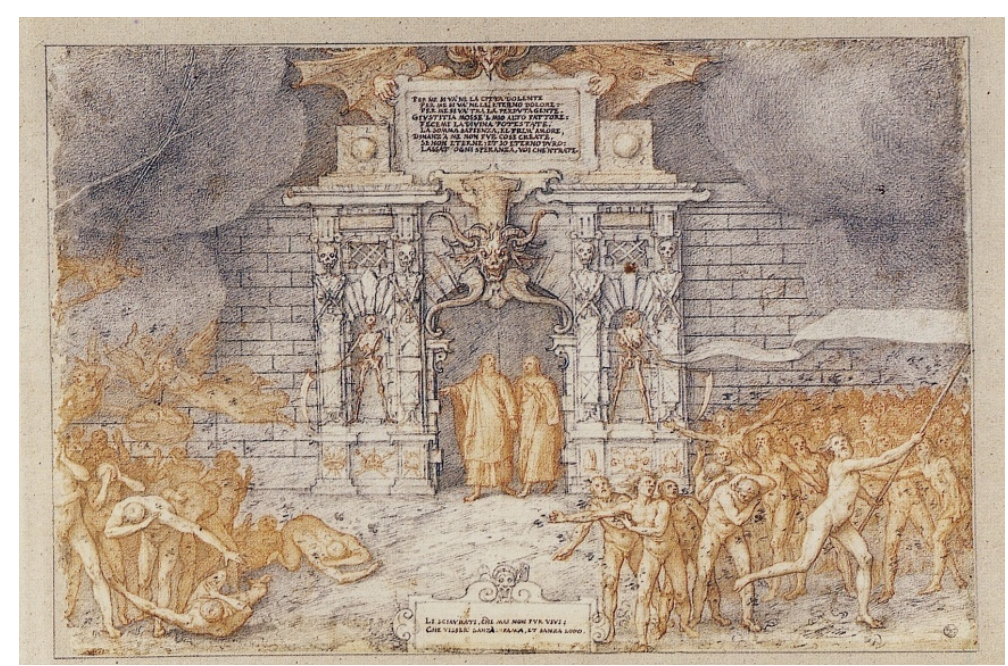

Figure 12. Federico Zuccaro, Inferno, Canto 1II, At the Gate, 1585, for Dante's Divine Comedy. Photo Courtesy of the Gabinetto dei Disegni e delle Stampe della Galleria degli Uffizi, Florence (Inv. 3475F).

For the illustration of Dante's Canto VII, ${ }^{48}$ Circle Four-The Hoarders and Wasters-Stradano visualized the poet's text and divided the sinners into two groups, illustrating how one group asks the other, "Why do you hoard?” The other group replies, "Why do you waste?” Unlike Stradano, Zuccaro did not divide the sinners into two groups but, instead, gathered them into a pigeonhole where all are nude and pushing large and weighty balloons of stone. Botticelli illustrated the tortuous punishment of avaricious and prodigal in their facial expression of the human nude figures (Figures 13, 14, 15).

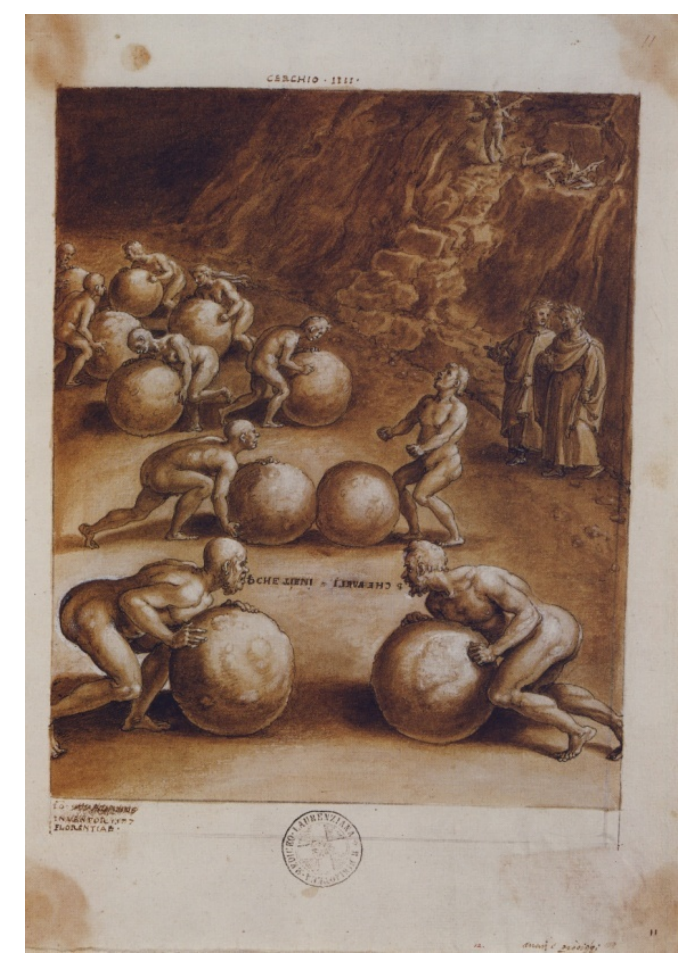

Figure 13. Giovanni Stradano, Inferno, Canto VII, The Hoarders and Wasters, 1588, for Dante's Divine Comedy. Photo: Public Domain. Wikemedia.org. Courtesy of the Biblioteca Laurenziana, Florence.

${ }^{48}$ See Philip R. Berk, “Canto VII: The Wheel of Fortune,” in Mandelbaum, et al., Inferno: A Canto-by-Canto Commentary, 101-110. 


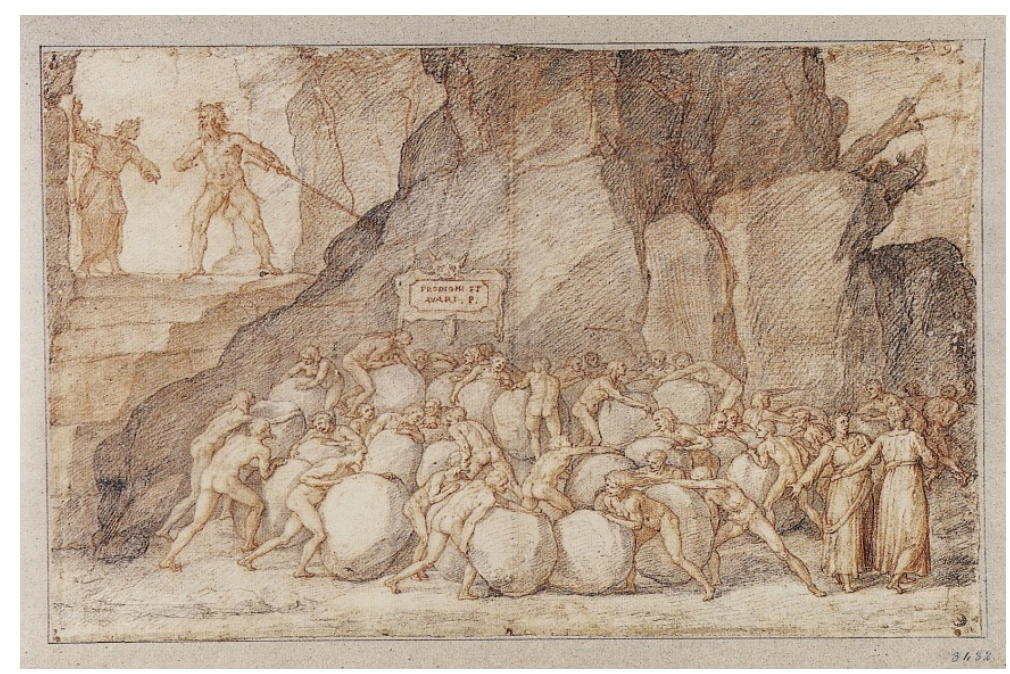

Figure 14. Federico Zuccaro, Inferno, Canto VII, The Hoarders and Wasters, 1585, for Dante’s Divine Comedy. Photo Courtesy of the Gabinetto dei Disegni e delle Stampe della Galleria degli Uffizi, Florence.

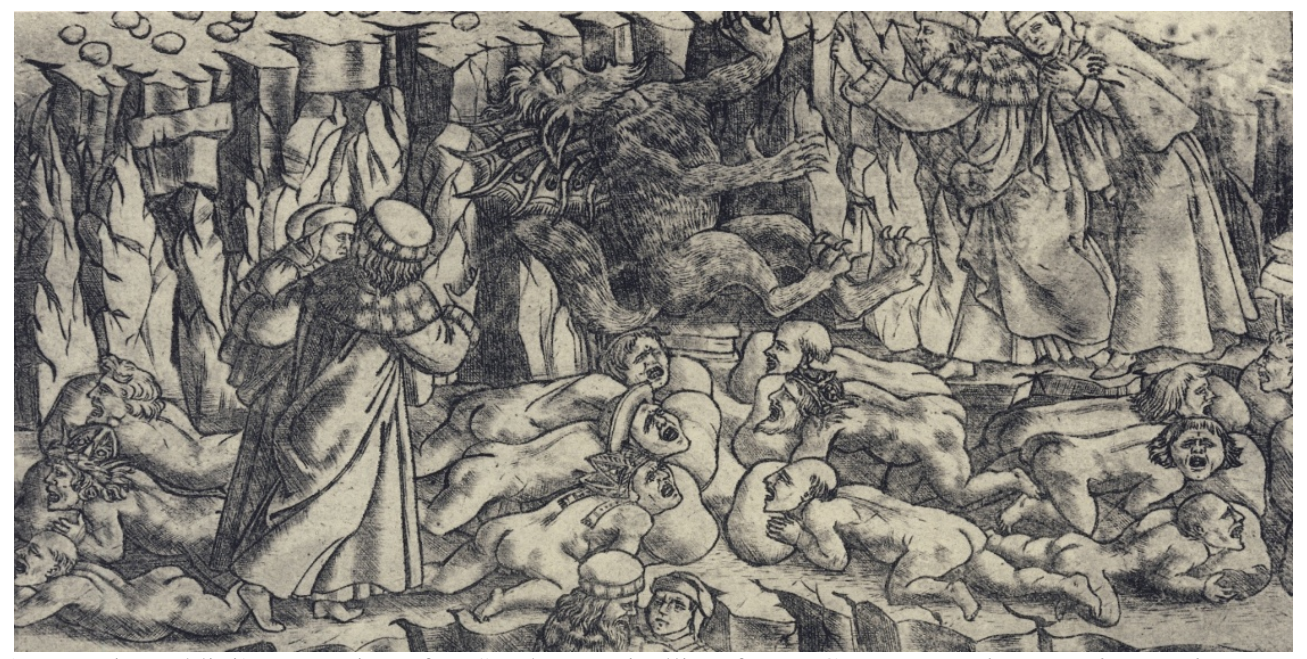

Figure 15. Baccio Baldini’s engraving after Sandro Botticelli, Inferno, Canto VII, The Hoarders and Wasters, 1481, for the first edition of Dante’s Divine Comedy. Photo: Public Domain. Courtesy of Biblioteca Riccardiana, Florence.

For the illustration of Dante's Canto VIII, ${ }^{49}$ Circle Five-The Wrathful—Dante's dramatic narrative of his journey to the City of Dis ("Roman" for the city of Hades or the capital of Hell) requires a panoramic view of the representation of Hell. For a manuscript illustrator, this canto presents numerous compositional and design challenges because of Dante's complex description of his perilous voyage to the infernal city, including Virgil's and his risks in descending into the fifth circle, navigating amidst the wailing sinners in the boat of Phlegyas along the Styx to reach the sixth circle, and experiencing demonic threats at the entrance of the City of Dis.

Stradano illustrated the anger of the sinners in the circle. Dante and Virgil can be seen in the boat of Phlegyas courageously transversing the River Styx amidst the wailing sinners. Zuccaro, instead, contrasted the monstrous-like rocky formation with the putrid River Styx. Dante and Virgil travel in the boat of Phlegyas on the Styx amidst the wailing sinners as well. But rebellious angels guard the infernal gate, refusing the poet's entry. Three infernal furies, symbols of eternal remorse, appear on the upper portion of the tower, exposing the

\footnotetext{
49 See Caron Ann Cioffi, “Canto VIII: Fifth Circle: Wrathful and Sullen,” in Mandelbaum, et al., Inferno: A Canto-by-Canto Commentary, 111-122.
} 
head of the Medusa, wishing for the poets to be transformed into stone. Virgil, symbol of human reason, promptly places his hands over Dante's eyes and seeks divine intervention, praying for a Heavenly Message. Upon his appearance at the City of Dis, the gate is opened and the poets enter unopposed. Botticelli masterfully interpreted Dante's narrative, but by organizing the imagery in descending spatial planes. Moreover, he aggrandized the role of Virgil as Dante's defender and protector by showing him forcefully arguing with the devils, although to no avail. However, after demonic threats and heavenly intervention, they successfully enter to the eternal city (Figures 16, 17, 18).

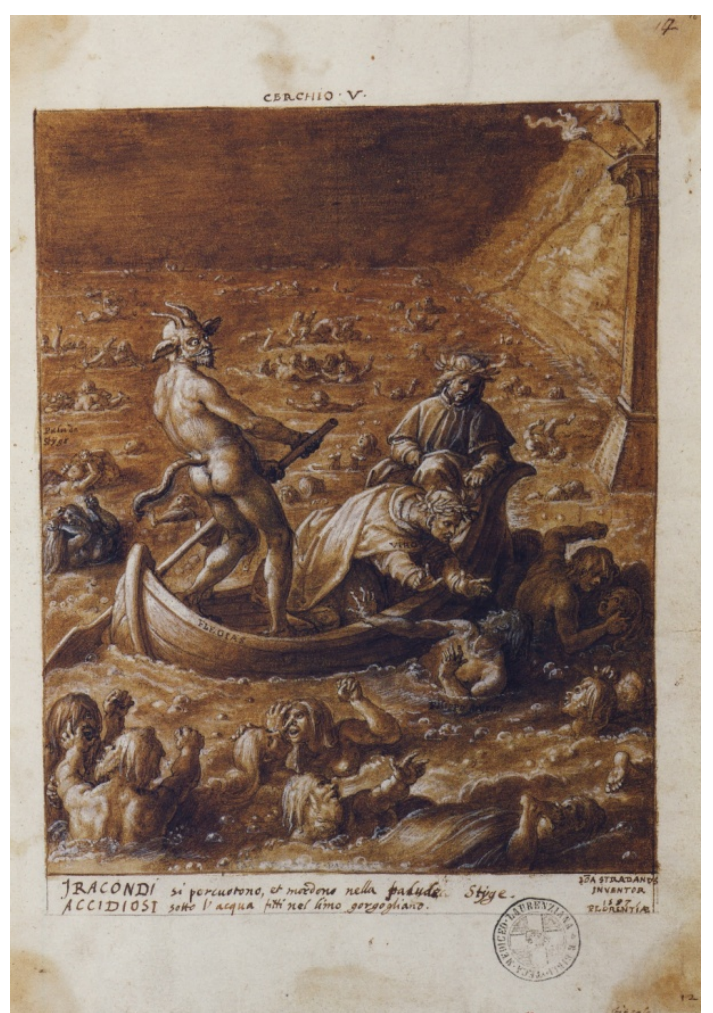

Figure 16. Giovanni Stradano, Inferno, Canto VIII, The Wrathful, 1588, for Dante’s Divine Comedy. Photo: Public Domain. Wikipedia.org. Courtesy of the Biblioteca Laurenziana, Florence.

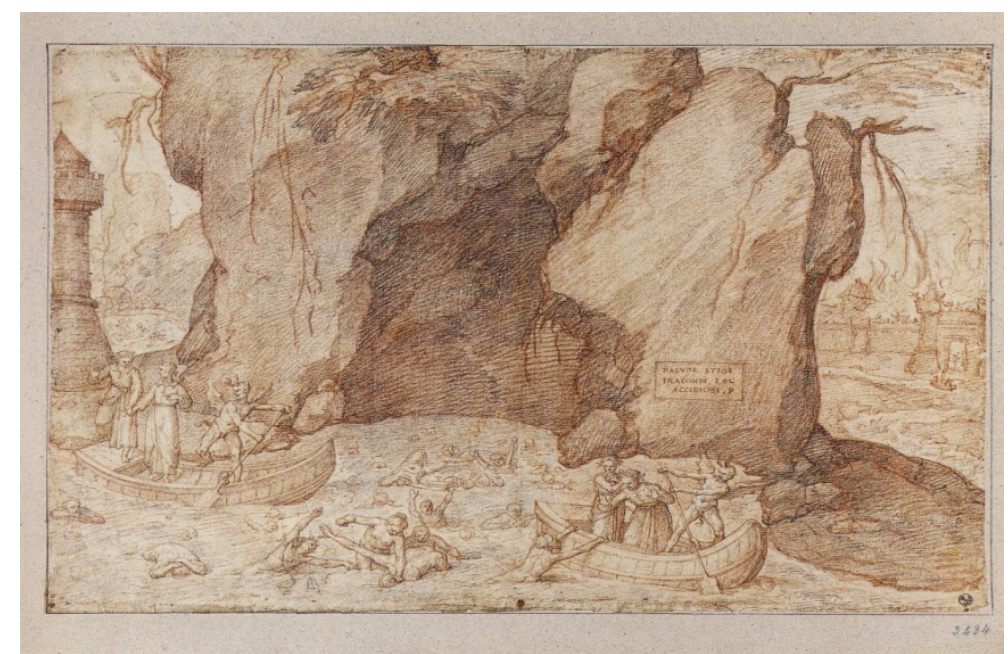

Figure 17. Federico Zuccaro Inferno, Canto VIII, The Wrathful, 1585, for Dante’s Divine Comedy. Photo Courtesy of the Gabinetto dei Disegni e delle Stampe della Galleria degli Uffizi, Florence. 


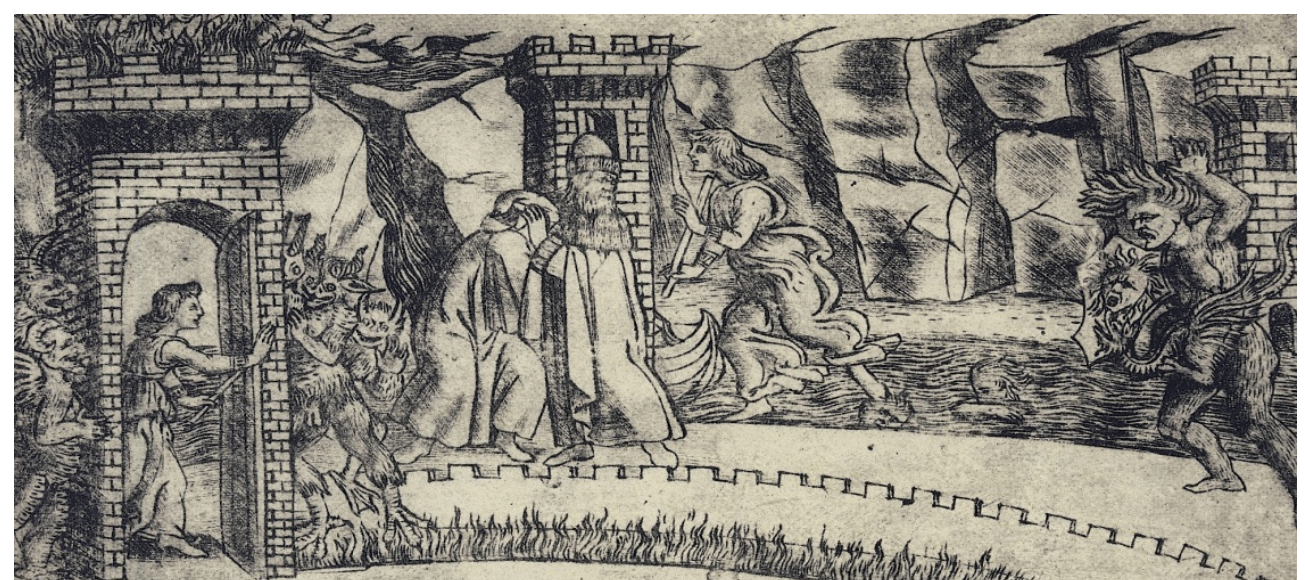

Figure 18. Baccio Baldini’s engraving after Sandro Botticelli, Inferno, Canto VIII, The Wrathful 1481, for the first edition of Dante's Divine Comedy. Photo Courtesy of Biblioteca Riccardiana, Florence.

For the illustration of Dante's Canto XVIII, ${ }^{50}$ Circle Eight (The Malebolge)—The Flatterers, or Adulators - Stradano dramatically visualized this canto. Geryon, the Monster of Fraud, is portrayed lacking wings, with a face of a king, the paws of a lion, the body of a half-reptile and half-hairy beast, and with a scorpion stinger at the end of his tail. In contrast, Zuccaro's Malebolge is less interpretative of the text and less explicit in the visualization of the scene, except in depiction of Geryon drawn with bat' wings. His Malebolge is a great amphitheater with slopes, ditches, and cliffs where the sinners are persecuted by figures of guilt. In contrast, Botticelli, like Stradano, visually elaborated upon Dante's scatological description of the fetid milieu by emphasizing the bestiality and ugliness of Geryon (Figures 19, 20, 21).

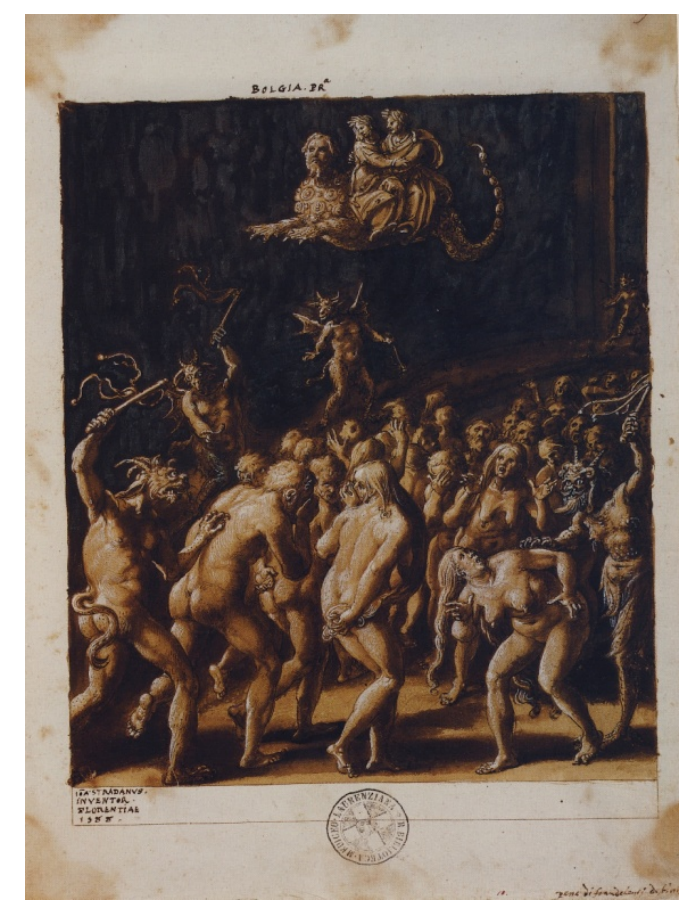

Figure 19. Giovanni Stradano, Inferno, Canto XVIII, The Malebolge, 1588, for Dante’s Divine Comedy. Photo: Public Domain. Wikepedia.org. Courtesy of the Biblioteca Laurenziana, Florence.

\footnotetext{
50 See James Nohrnberg, “Canto XVIII: Introduction to Malebolge,” in Mandelbaum, et al., Inferno: A Canto-by-Canto Commentary, 238-261.
} 


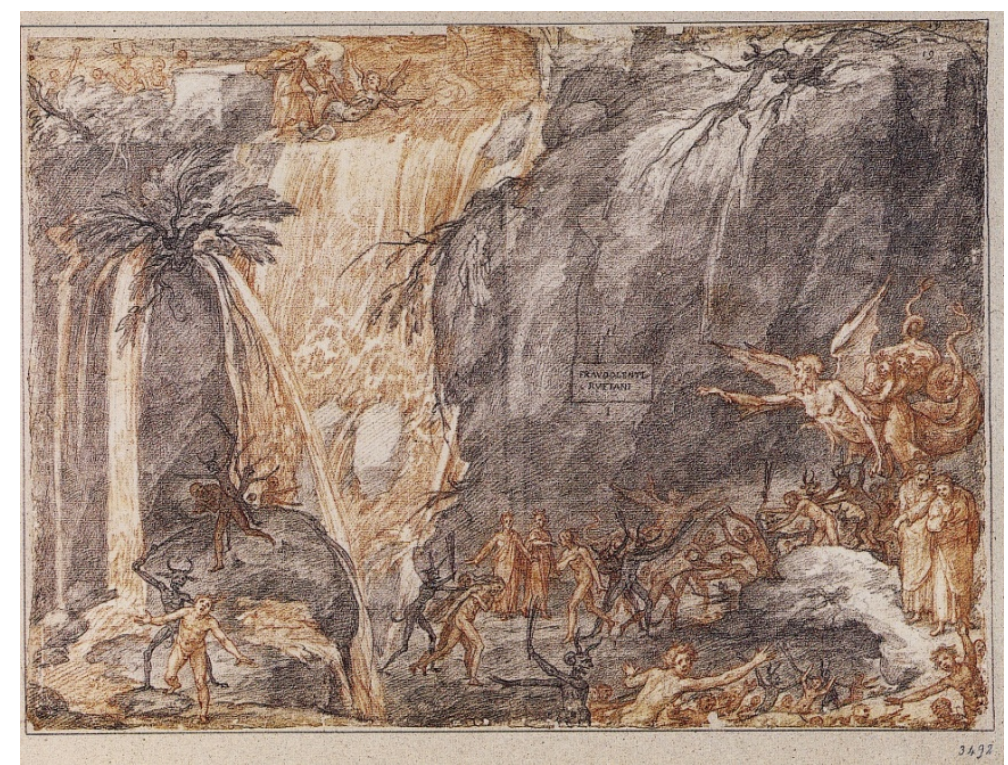

Figure 20. Federico Zuccaro, Inferno, Canto XVIII, The Malebolge, 1585, for Dante’s Divine Comedy. Courtesy of the Gabinetto dei Disegni e delle Stampe della Galleria degli Uffizi, Florence.

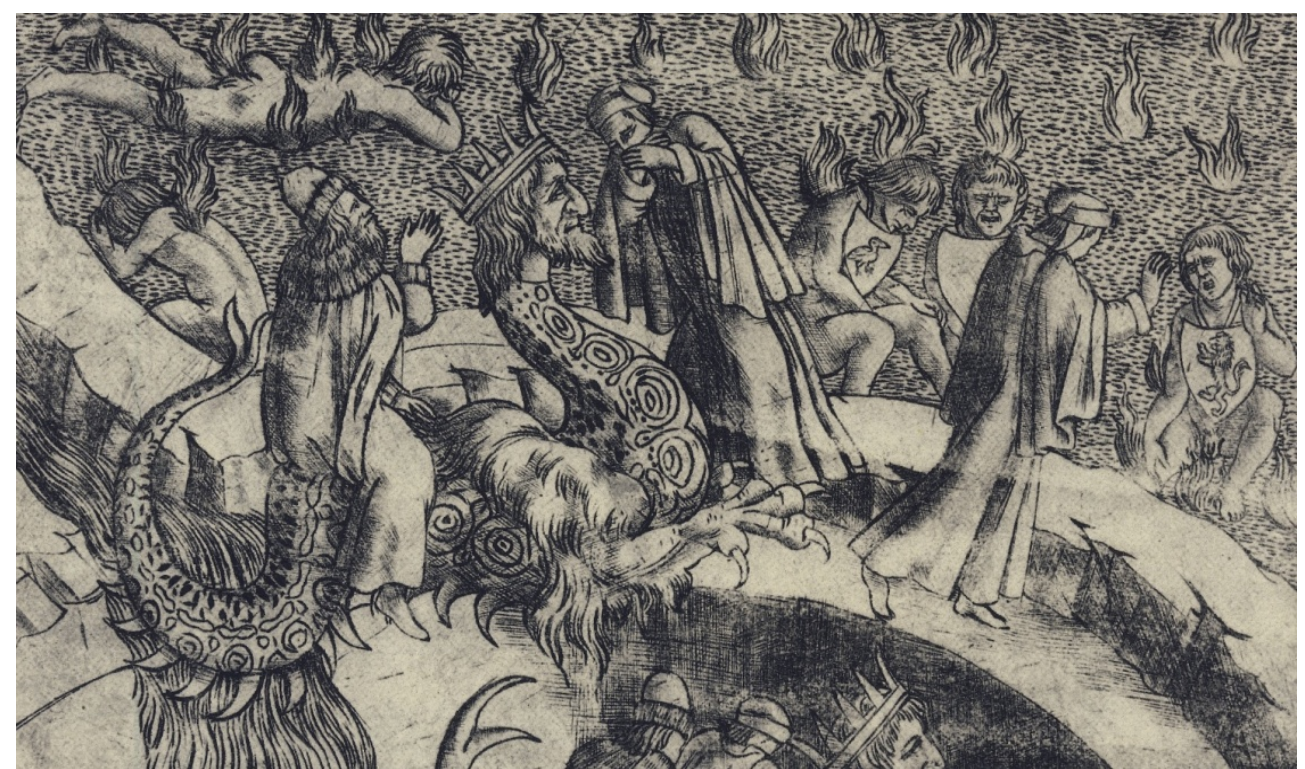

Figure 21. Baccio Baldini’s engraving after Sandro Botticelli, Canto Canto XVIII, The Malebolge, 1481, for the first edition of Dante's Divine Comedy. Photo Courtesy of Biblioteca Riccardiana, Florence.

For the illustration of Dante's Canto XXXIII, ${ }^{51}$ Circle Nine (Cocytus [The River of Wailing])—Compound Fraud—Stradano illustrated the pathetic and terrible story of Count Ugolino della Gherardesca's (1220-1289) final days on earth. The traitors are locked in the frozen River Cocytus. However, Stradano drew Ugolino and Archbishop Ruggieri degli Ubaldini (active 1270-1295) residing together in a pit set apart from the other traitors, symbolizing how they plotted together during their lifetime. Stradano's imagery draws from Dante's condemnation of Ruggieri for betraying Ugolino and for imprisoning him with his four sons and starving them to death. Dante asks Ugolino to recount his story. Zuccaro's drawing for this Canto

\footnotetext{
${ }^{51}$ See Edoardo Sanguineti, “Canto XXXIII: Count Ugolini and Others,” in Mandelbaum, et al., Inferno: A Canto-by-Canto Commentary, 424-431.
} 
is absent from the text-perhaps it has disappeared or was never executed. In the second edition of Dante's Inferno, Botticelli composed a dramatic scene where in a paradoxical space—confined and vast—-traitors depicted as nude figures tumble in vortices of cannibalism. In the center of this scene, Dante and Virgil stop to hear Ugolino's story (Figures 22 and 23).

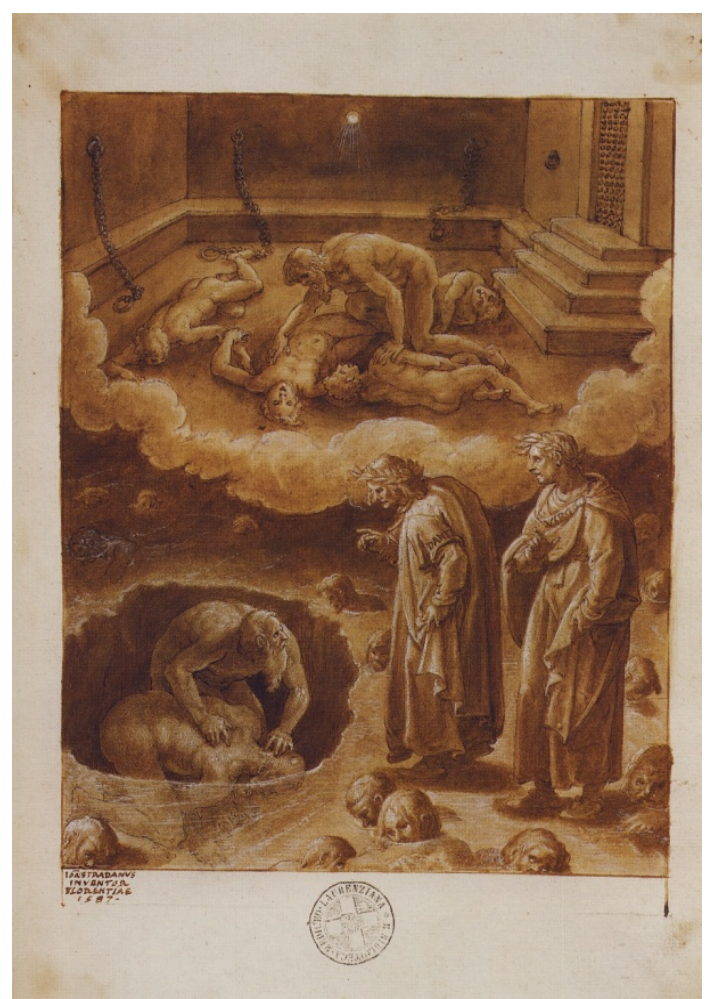

Figure 22. Giovanni Stradano, Inferno, Canto XXXIII, Cocytus, Compound Fraud, 1588, for Dante’s Divine Comedy. Photo: Public Domain. Wikemedia.org. Courtesy of the Biblioteca Laurenziana, Florence.

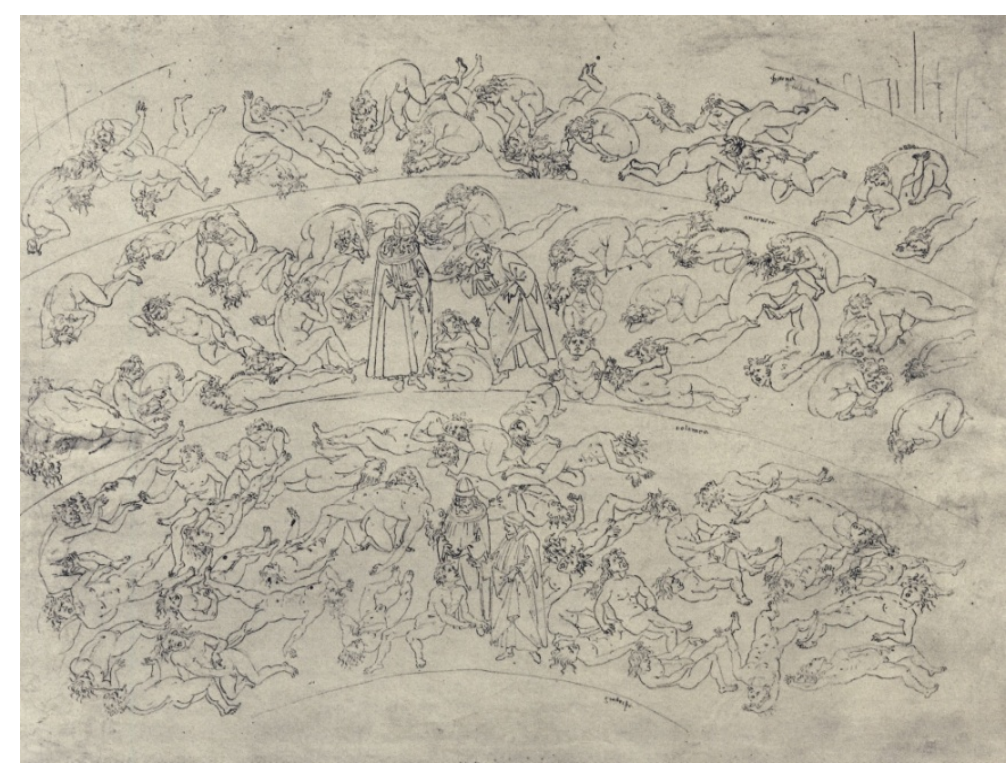

Figure 23. Sandro Botticelli, Inferno, Canto XXXIII, Cocytus, Compound Fraud, 1482-90, for the second edition of Dante’s Divine Comedy. Photo Courtesy of Kupferstichkabinett, Staatliche Museen, Berlin/Philipp Allard. 
The last canto of Dante's Inferno is Canto XXXIV, ${ }^{52}$ Circle Nine (Center)—Satan or Lucifer. Stradano's terrifying image of a standing Lucifer or Simia Dei assimilated Dante's description of the winged and immobile Satan standing and surrounded by falling sinners. He is fixed into the ice of the center, to which flow all the rivers of guilt, and as he beats his great wings as if to escape, the icy wind only freezes him more surely into a glacial abyss. Simia Dei looks to heaven with hopelessness. The fearful poets climb with difficulty through the center, emerging from Hell into Mount Purgatory. In contrast, Zuccaro portrayed Dante's winged and horned Simia Dei devouring sinners while standing immobile. Compared to Stradano's image, Zuccaro's Simia Dei is less human and bestial in design. The very large bat wings echo his clawed feet. This image of Satan or Lucifer is composed of three horned heads, a parody on God's Trinity. ${ }^{53}$ The fearful poets can be seen several times in the drawing, escaping with great difficulty from Hell into Mount Purgatory. Botticelli drew two versions of the Simia Dei-one of a half image and another of a full standing figure. The full-size figure is that of an ugly, hairy monster, with three horned heads. They consume the malefactors with disgust. The poets struggle to escape from this tormenting circle of hell. The originality of Dante's Lucifer rests on his immobility, his being locked in ice, and his inability to see God. These artists portrayed a personal interpretation of this horrifying scene- - the Visio Tundali (Figures 24, 25, 26).

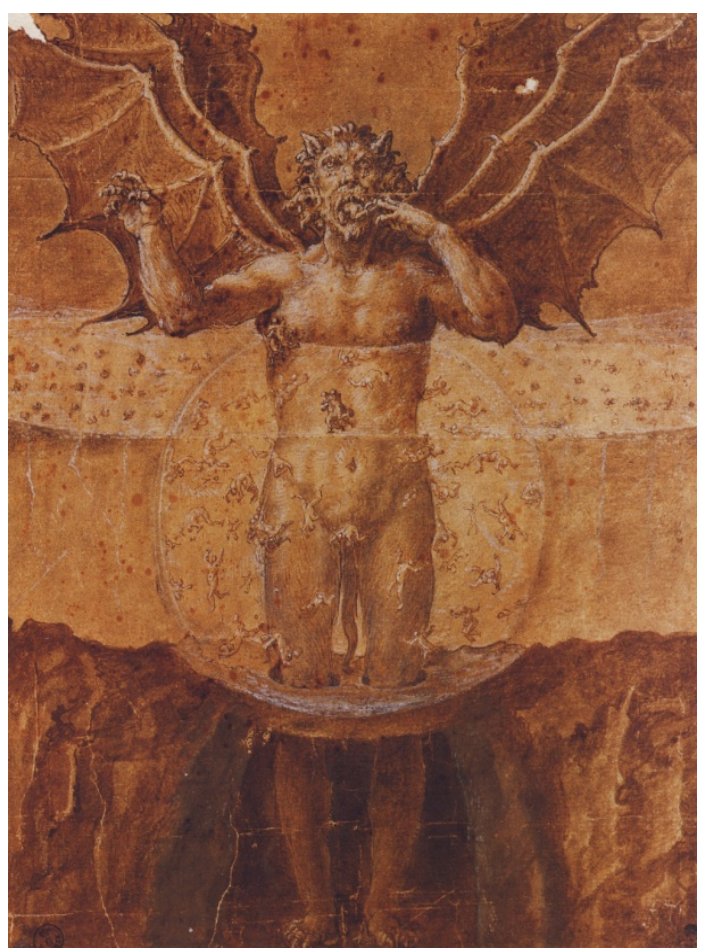

Figure 24. Giovanni Stradano, Inferno, Canto XXXIV, Circle 9, Satan or Lucifer, 1588, for Dante’s Divine Comedy. Photo: Public Domain. Wikepedia.org. Courtesy of the Gabinetto dei Disegni e delle Stampe della Galleria degli Uffizi (N. 2739), Florence.

\footnotetext{
52 See Remo Ceserani, “Canto XXXIV: Lucifer,” in Mandelbaum, et al., Inferno: A Canto-by-Canto Commentary, 432-439. 53 In 1579 in the dome of Santa Maria del Fiore, Cathedral of Florence, Zuccaro painted a similar Simia Dei in the Last Judgment scene. After Vasari's death in 1574, Zuccaro was responsible for completing the frescoes in the dome.
} 


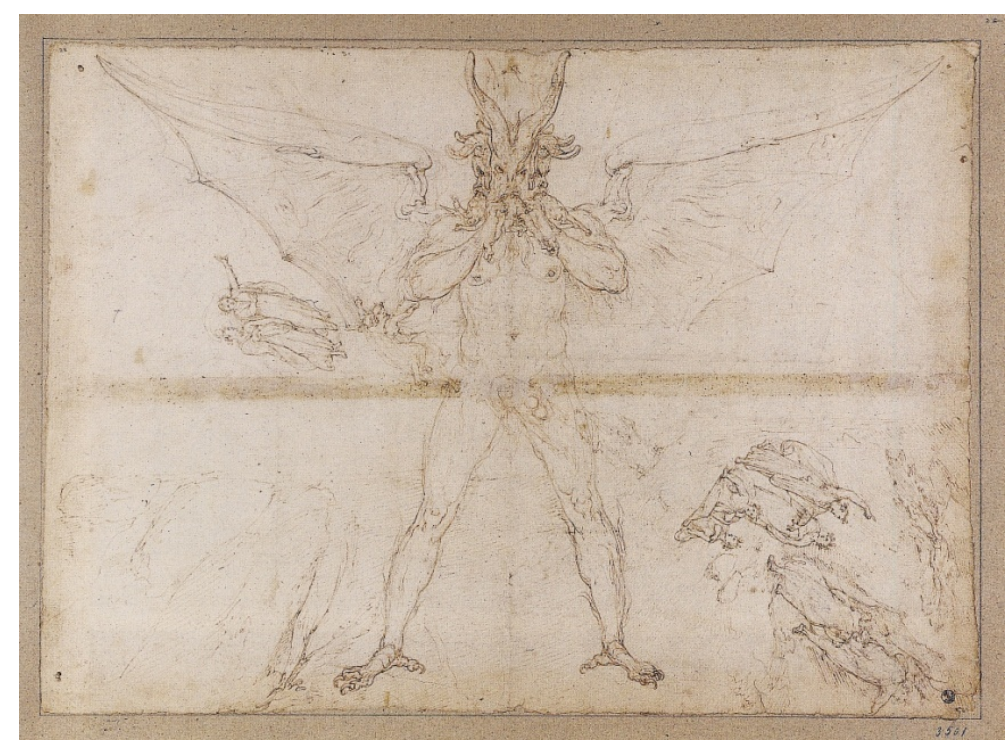

Figure 25. Federico Zuccaro, Inferno, Canto XXXIV, Circle 9, Satan or Lucifer, 1585, for Dante’s Divine Comedy. Photo Courtesy of the Gabinetto dei Disegni e delle Stampe della Galleria degli Uffizi, Florence.

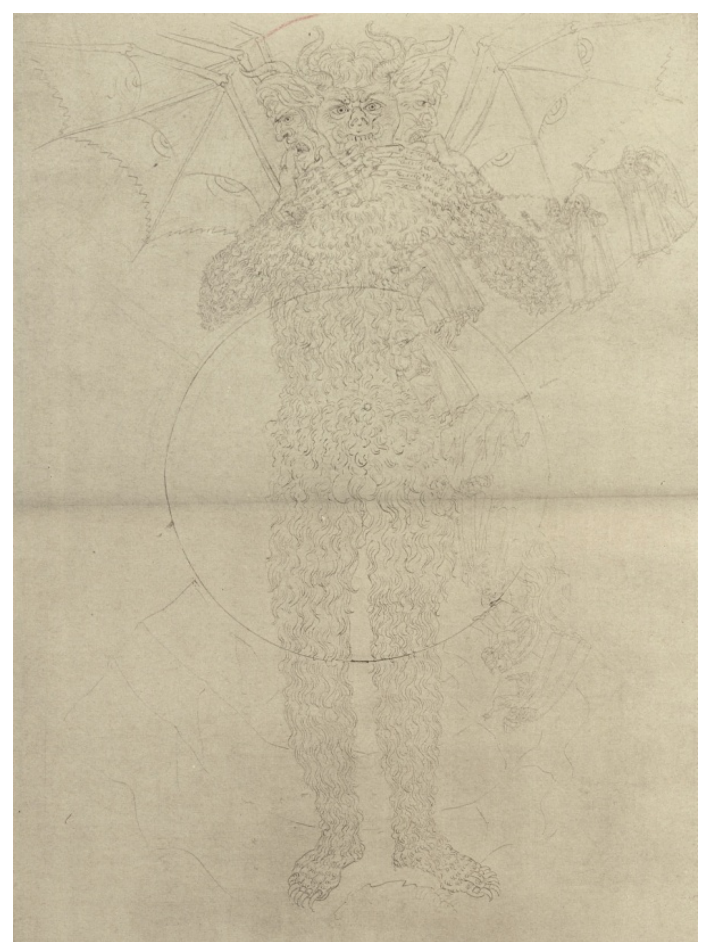

Figure 26. Sandro Botticelli, Inferno, Canto XXXIV, Circle 9, Satan or Lucifer, 1482-1490, for the second edition of Dante’s Divine Comedy. Photo Courtesy of Kupferstichkabinett, Staatliche Museen, Berlin/Philipp Allard.

When comparing the drawings of Botticelli and Stradano with those of Zuccaro for Dante's Inferno, Stradano's drawings lack text in the design and represent a vivid interpretation of his reading Dante's text. In the treatment of the human figure, Stradano captured Dante's narrative and aroused empathy in the viewer. Botticelli's drawings carefully follow Dante's text, and the drawings themselves contain no text. In contrast, Zuccaro's drawings contain headings, epitaphs, and brief references to Dante's text. He captured Dante's allegorical narrative in two complex spatial constructs: architectural designs of gates and walls filled with 
bucrania (ox skulls) and skeletal ornamentation; and landscapes with huge rocky formations and gigantic, twisted trees. These are impenetrable spaces in which human beings will never find freedom. Zuccaro is teaching the reader to see. Botticelli gave equal weight to word and image by placing text on the left side of the page and illustrations on the right, whereas Zuccaro combined the word with the image, with the illustration containing captions or small scripts in framed squares. Botticelli allowed the viewer to read and reflect on the text and then view its accompanying illustration; Zuccaro selected the text and incorporated it into the illustration, thus providing the viewer with a visual reading of Dante's Inferno. Zuccaro, visually and literally, taught Dante's text to the viewer through his images and words. The visualization of the poem can be interpreted as the culmination of the ancient conceit of ut pictura poesis. ${ }^{54}$ It may be asked why Zuccaro was concerned with this pedagogical approach. ${ }^{55}$ By reflecting on his academic training and the development of art theories of his time, his purpose in illustrating Dante's Divine Comedy can be understood.

Zuccaro's theory of art was designed to answer one question: "How does an artist create a work of art?" His answer: through design, creativity is manifested. Thus his theory of art stresses the theory of design - internal and external (disegno interno e disegno esterno). Dante had asked a similar question years before: "How does a poet create a work of art?" His response manifested itself in his poema sacro. For Zuccaro, then, Dante represented the artistic genius who, in the process of answering his question, had also revealed to him the way in which to achieve this creativity. As a consequence, Zuccaro, in his drawings for Dante's commedia, displayed his artistic skills by visualizing Dante's words as well as his poetic interpretation in comprehending Dante's meaning of life.

Following Giorgio Vasari’s footsteps in the creation of the Accademia del Disegno (1562) in Florence, ${ }^{56}$

\footnotetext{
54 The phrase originates from Horace's Arts poetica (line 361), first century BCE. For further study, see Horace on Poetry: The Ars Poetica, ed. C.O. Brink (Cambridge: Cambridge University Press, 1971). But in the Renaissance, Cristoforo Landino (1424-1498) popularized Horace's phrase in his edition of Horatius cum quattuor commentariis (Venice: Johannes Alvisius, 1498), citing Horace’s passage: “ut pictura poesis erit.i. non erit dissimilis/poetica ars picturae.” See Jean H. Hagstrum, The Sister Arts: The Tradition of Literary Pictorialism and English Poetry from Dryden to Gray (Chicago: University of Chicago Press, 1958), 59; and Mario Praz, Mnemosyne: The Parallel Between Literature and the Visual Arts (Princeton: Princeton University Press, 1967), 2-28.

${ }_{55}$ Zuccaro was a famous and internationally renowned artist, and he became the first president of the new Roman Academy of Saint Luke, which he founded in 1593. The early meeting of the academy occurred in Federico's house, in the Pincian Hill, at the corner of Via Gregoriana and Via Sistina (now the seat of the Bibliotheka Hertziana), which he later decorated in 1598 and gave to the Academy for its headquarters (see the classic study of Werner Körte, Der Palazzo Zuccari in Röm [Leipzig: H. Keller, 1935]). Along with many of his contemporaries, Zuccaro believed that correct theory would produce good works of art. He wrote L'Idea de' Pittori, Scultori ed Architetti, Vol. 2 (Turin: Agostino Disserolio, 1607, French edition). For fifteen years Zuccaro attempted to reform the Accademia del Disegno in Rome. He was eventually successful with the assistance of Cardinal Federico Borromeo (1564-1631). On November 14, 1593, the Academy was inaugurated in the church, and Federico Zuccaro was elected as its president (principe). The instruction and discussions on art were organized in the following manner. Every day they attended mass. After the service students would listen to theoretical debates about art initiated by Zuccaro. Romano Alberti, Zuccaro's nephew, recorded these lectures. The artistic ideas that evolved as a result of these debates and the compiled explanatory notes served as a foundation for Zuccaro's book. Through Alberti's notes we know that the lectures dealt with two factors: instruction and theory. The aspect on instruction focused on the artist's education; explanations and definitions on the basics of paintings; theories of art postulated by Aristotle, Thomas Aquinas, Leon Battista Alberti, Albrecht Dürer, Ludovico Dolce, Giorgio Vasari, and Gian Paolo Lomazzo; and explanations on the metaphysical and theological nature of design (disegno). According to Freedberg, Zuccaro was the "most systematic and the most lucid" on the aesthetics of Maniera because of his intellectual investigations on the creation of art. See Sydney Freedberg, Painting in Italy: 1500-1600 (London: Yale University Press, 1993), 646. Federico Zuccaro died in Ancona on August 6, 1609.

${ }^{56}$ See Paola Barocchi, ed., I Fondatori dell'Accademia del Disegno [The Founders of the Academy of Design] (Florence: L. S. Olschki, 1964); and Zygmunt Wazbinski, L'Accademia medicea del Disegno a Firenze nel Cinquecento [The Medicean Academy of Design in Florence in the Sixteenth Century] (Florence: L. S. Olschki, 1987), for a seminal study on this topic. For an adapted study in English of these two Italian books, see Karen Edis-Barzman, The Florentine Academy and the Early Modern State. The Discipline of Disegno (Cambridge: Cambridge University Press, 2001).
} 
Zuccaro also organized a drawing academy, the Accademia di San Luca, in Rome and became its first president in $1593 .^{57}$ The Accademia emphasized practical instruction and theoretical lectures, with the aim of creating social prestige for the artist. These ideas evolved into a theory of art or aesthetics described in a handbook for artists on rules and procedure with a sizable theoretical text entitled L'idea de' pittori, scultori ed architetti [The notion of painters, sculptors and architects]. ${ }^{58}$

Unlike Vasari, Zuccaro did not instruct the artists on how to make a work of art. His concern was how the notion of art appears in the mind of the artist and how it is translated into a drawing. Zuccaro's famous table on the property and quantity of design clearly explains how the artist's idea moves from God to work of art. In Aristotelian fashion, he described the process for design: from the abstract concept of the idea to the practical or material execution of the design idea. Beginning at the top of Zuccaro's diagram, a divine spark suggests the name, followed by the properties or qualities of circumscription, mensuration, and form (image). These qualities in turn give substance to form and figure by simple outlines. This appearance reveals the light of the intellect, represented through the instruments of pencil or pen. The result creates a design.

As a Christian of the sixteenth century, Zuccaro explained the origin of design or disegno in terms of the number three, symbolic of the Trinity, which composes God's name: di-segn-o or Dio (the Italian word for God), and segn (Italian word for segno or sign) for design. ${ }^{59}$ In his writings, Zuccaro was influenced by Thomas Aquinas' concept of God in Summa theologiae (I, l-15: “God, as a creator, also ‘designs' internally and externally, so to speak"). Zuccaro commented also that the structure of the word disegno contains "the true sign

\footnotetext{
57 The biographies of Giorgio Vasari (Le vite de' piú eccellenti pittori, scultori ed architettori [The lives of the most excellent painters, sculptors and architects] [Florence: Giunti, 1568]); and Giovanni Baglione, Le vite de'pittori, scultori ed architetti [The lives of painters, sculptors and architects]. [Rome: Andrea Fei, 1642]) remain the most complete writings on the lives of Federico (1540/2-1609) and his brother, Taddeo Zuccaro (1529-1566). Contemporary scholars also provide us with greater insight on Taddeo's and Federico's achievements, for example, John Gere's many writings on these masters, particularly the excellent study on Taddeo Zuccaro (Chicago: University Chicago Press, 1969) and Freedberg's analysis of the Zuccari’s style in Painting in Italy: 1500-1600 (Baltimore: Pelican History of Art, 1979). For specialized studies consult Delft Heikamp's continuous research on Federico, particularly the laborious article “Federico Zuccaro a Firenze: 1757-1579,” Paragone (March 1967), 44-68, which examines Federico's intervention and completion of the frescoes for the dome of the cathedral in Florence after the death of Giorgio Vasari in 1572; in the second article in Paragone (May 1967), 1-34, Heikamp reviews the history of Federico's houses in Florence and Rome. For the literature on iconographic interpretations, review two significant studies by Loren W. Partridge: "The Sala d' Ercole in the Villa Farnese at Caprarola," Art Bulletin (December 1971), 467-486; (March 1972), 50-62; and "Divinity and Dynasty at Caprarola: Perfect History in the Room of Farnese Deeds," Art Bulletin (September 1978), 449-530. For other influential publications on Federico's accomplishments on the formation of the Academy of Art and their writings on art theories, examine the writings of Detlef Heikamp, ed., Scritti d'Arte ([Writings on Art]. Florence: L.S. Olschki, 1961), which contains Federico Zuccaro's Lettera a Principi [Letter to Princes], 1605; L'Idea de' pittori, scultori ed architetti [The Conceits of Painters, Sculptors and Architects], 1607; and, R. Alberti, Origine e progresso dell'Accademia del Disegno di Roma [The Origin and Progress of the Roman Drawing Academy], 1607. Additional critical studies on Federico's theoretical writings are Erwin Panofsky's "Zuccari: The Aristotelian-Thomistic Trend,” in Erwin Panofsky, Idea: A Concept in Art Theory (Columbia: University of South Carolina Press, 1968); Moshe Barasch, "Zuccari: The Theory of Disegno," in Theories of Art: From Plato to Winckelmann (New York: New York University Press, 1985); Ghislain Kieft, “Zuccari, Scagliero e Panofsky,” Mitteilungen des Kunsthistorischen Institutes in Florenz 33.2/3 (1989), 355-368; and Serge Trottein, "L'idée des Artistes: Panofsky, Cassirer, Zuccaro et la théorie de l'art” [“Artists' ideas: Panofsky, Cassirer and Zuccaro and the theory of art], Racar/Société pour Promouvoir la Publication en Histoire de l'Art au Canada 37.2 (2012), 19-26.

${ }^{58}$ The text was written earlier but published in Turin in 1607. During this Maniera time, there was a strong historical consciousness. Many artists wrote travelogues because the living conditions for artists were difficult and the competition was fierce, to the point of trials, lawsuits, and appeals, as in the case of Federico Zuccaro being slandered by a Bolognese artist and subsequently being punished and banished from Rome without a fair trial by Pope Gregory XIII (see Federico's Letter to Princes of 1605). Because of these difficulties, artists decided to establish academies for the protection of their rights and for the interchange of artistic ideas. Zuccaro not only founded a Roman academy of drawing in 1593 but also wrote a treatise on art. This theoretical treatise has received little attention from art historians, except for Panofsky's "Zuccari: The Aristotelian-Thomistic Trend," 85-93; and Gizzi, Federico Zuccari e Dante, 13-22, on Zuccaro’s theory of art and Mannerism.

59 Panofsky, "Zuccari: The Aristotelian-Thomistic Trend,” 88.
} 
of God within us" (vero segno di Dio in noi). ${ }^{60}$ Design extends from the internal to the external, from the image in the mind to the drawing on paper. Zuccaro stated that "one should remember that there are two kinds of operations: external ones like drawing, outlining, shaping, caring, and building; and internal ones like reasoning and desiring.”61 Internal design is a concept or idea formed in the artist's mind by God, and external design or artistic representation is the manifestation on paper of that concept or idea. Internal design is "free from its execution in any artistic medium." ${ }^{62}$ Thus the drawings for Dante's Divine Comedy represent Zuccaro's theory of art, where drawing manifests artistic creativity as Dante's poema sacro. Both artists—painter and poet—allude to the ut pictura poesis conceit and to furor poeticus (impetus of the poet).

\section{Conclusion}

The drawing illustrations of Botticelli, Stradano, and Zuccaro reveal how these artists captured Dante's poetical imagery through a variety of artistic processes and interpretations. Artists and poet alluded to Horace's ut pictura poesis conceit "as is painting so is poetry." 63 This notion about artistic creativity combined the conception of poetic inspiration with visual forms and vice versa. ${ }^{64}$ The phrase was frequently employed by artists and theoreticians of the sixteenth century, including Leonardo da Vinci, Ludovico Dolce, Gian Paolo Lomazzo, and Giorgio Vasari. ${ }^{65}$ The idea of ut pictura poesis captures the complementary nature of poetry or writing with painting, equating the inspiration of the poet and writer with the imagination of the painter. ${ }^{66}$ Both are concerned with the conception of creativity and imitation of nature: the painter through the use of visual elements (line, color, tone, texture, and shape); the poet or writer through words. Leonardo, commenting on the versatility of the painter, remarked about this parity, which Dante captures in his poema sacro.

Be chè questo non dico per biasimare simili openioni, perchè ogni fatica aspetta premio, e potrà dire un poeta, io farò una finzione che sinifica cose gradi, questo medesimo farà il pittore, come fece Apelle la Calunnia; se voi diceste la poesia è piu eterna, per questo dirò essere piu eterne le opera d'un calderaio, chè 'l tepo piu le conserva che le vostre e nostre opere; niete di meno è di poca fantasia; e la pittura si può, dipingniedo sopra rame con colori di vetro, fare molto piu eterna; noi per arte possiamo essere detti nipoti a Dio; se la poesia s'astende la filosofia morale, è questa la filosofia naturale, se quella descrive l'operationi della mente, questa considera quello che la mente opera nei movimenti: se quella spaveta I popoli colle infernali vitioni, questa colle medesime cose in atto fa il simile: ponga si il poeta a figurare una belezza, una fierezza, una cosa nefada e brutta, una mostruosa col pittore, faccia a suo modo come vole trasmutationi di forme, che il

\footnotetext{
${ }^{60}$ Ibid., 85-86.

${ }^{61}$ Ibid., 86.

62 Ibid., 91.

63 See note 54.

${ }^{64}$ Michael J. B. Allen, Marsilio Ficino and the Phaedran Charioteer (Berkeley: University of California Press, 1981), 339-439; André Chastel, Marsile Ficin et L'Art (Geneva: Droz, 1954), 81-89.

65 See John R. Spencer, "Ut Rhetorica Pictura: A Study in Quattrocento Theory of Painting," Journal of the Warburg and Courtauld Institutes 20 (1957), 26-44; Anthony Blunt, Artistic Theory in Italy (Oxford: Oxford University Press, 1968), 52; Rensselaer Lee, Ut Pictura Poesis: Humanist Theory of Painting (New York: W. W. Norton and Company, Inc., 1967), 1, n. 2; Dolce's Dialogo della Pittura (1557), trans. M. Roskill (New York: New York University Press, 1968), 97 and 239; and Gian Paolo Lomazzo's Trattato dell' arte della pittura, scultura et architettura [Treatise on the art of painting, sculpture and architecture]. (Milan: Paolo Gottardo Pontio, 1584), which summarizes Leonardo's and Dolce's conceptions of the relationships between poetry and painting. Also, Giorgio Vasari noted: "I confirm that poetry and painting as sister arts employ similar terms" (“atteso che la poesia e la pittura usano come sorelle i medesimi termini”; Vasari, Le Vite dei piú eccellenti pittori, sculptori et architetti, 8: 18.

${ }^{66}$ Horace: Epistles Book II and Arts Poetica, trans. H. Rushton Fairclough (Cambridge, MA: Harvard University Press (Loeb Classical Library, No. 194), 1929, revised), Ars Poetica, lines 10-11: Pictoribus atque poetis quidlibet audendi semper fuit aequa potestas" [But painters and poets have always shared the right to dare anything], and lines 38-39: "Sumite materiam uestris qui scributus, aequam uiribus et uerstate diu quid ferre recusant..." [You who write choose a subject that's matched by your powers...].
} 
pittore non sadisfacci piu, non s’è egli viste pitture avere tanta conformità colla cosa viva ch’ell’a iganato homini e animali?

[And if a poet should say: "I will invent a fiction with a great purpose," the painter can do the same, as Apelles painted the Calumny. If you were to say that poetry is more eternal, I say the works of a coppersmith are more eternal still, for time preserves them longer than your works or ours; nevertheless they have not much imagination. And a picture if painted on copper with enamel colors may be yet more permanent. We, by our arts may be called the grandsons of God. If poetry deals with moral philosophy, painting deals with natural philosophy. Poetry describes the action of the mind, painting considers what the mind may effect by the motions. If poetry can terrify people by hideous fictions, painting can do as much by depicting the same things in action. Supposing that a poet applies himself to represent beauty, ferocity, or a base, a foul or a monstrous thing, as against a painter, he may in his way bring forth a variety of forms; but will the painter not satisfy more? Are there no pictures to be see, so like the actual things, that they deceive men and animals?]. ${ }^{67}$

In this statement, there is also an allusion to the Renaissance Neoplatonic concept of furor poeticus or poetic inspiration, which derives from the writings of philosopher Marsilio Ficino. Ficino explained in his Orphic writings that there are four forms of inspiration or furor: divine, prophetic, amorous, and poetic. ${ }^{68}$ Considering Ficino's philosophical influence in the arts of Renaissance, I would like to coin Ficino’s inspirational fire as a particular type of furor, a furor artisticus, a unique artistic frenzy of visual artists. ${ }^{69}$ The explanation of artistic inspiration is based fundamentally on the Italian Renaissance tradition, which considers creativity to be a faculty present in all of human activity, ${ }^{70}$ indicated not only in the writings of Zuccaro but also in Vasari, who noted: “Thus [creativity must be activated] when the intellect (l'ingegno) wants to work, and when the fire of inspiration is kindled (il furore e acceso), because it is then that one sees excellent and divine results, and marvelous conceptions (concetti meravigliosi). ${ }^{71}$ The notion of artistic creativity combined with the concept of poetic inspiration and ut pictura poesis is encapsulated in these drawings of the Dante's poema sacro.

These Cinquecento artists provided a new pictorial world of artistic mysteries and phantasmic visions in which the illustration of Dante's poema sacro, in particular Hell, evolved over and over, manifesting the eternity of life not just in its evilness but also in its beauty. As Dante, turning to Beatrice, in Canto XXXIV of Paradiso, says with hope: A quindi uscimmo a riveder le stelle (And so we walked out, once more beneath the stars).

\footnotetext{
${ }^{67}$ The Literary Works of Leonardo da Vinci (Scritti Letterari di Leonardo da Vinci cavati dagli autografi e pubblicati), ed. Jean Paul Rickter (London: Sampson Low, Marston, Searle \& Rivington, 1883), 328-329, and Notebooks, 654-655.

68 See Jayne Sears, “Ficino and the Platonism of the English Renaissance,” Comparative Literature 4 (Summer 1952), 214-238; Michael J.B. Allen, Marsilio Ficino and the Phaedran Charioteer (Los Angeles: University of California Press, 1981), 339-439; and Allen, The Platonism of Marsilio Ficino, 41-67, for a reference to the four types of divinus furor in Ficino's writings, in particular, in his Commentary on Plato's Symposium (7:14): “The four divine furors are first poetical, then mythical, third prophetic and amorous fourth” (“Quatuor ergo divini furoris sunt speties. Primus quidem poeticus furor, alter mysterialis, tertius vaticinium, amatorious affectus est quartus”). See also Paul Oskar Kristeller, ed., The Letters of Marsilio Ficino, Preface by Paul Oskar Kristeller, trans. and ed. from Latin by members of the Language Department of the School of Economic Science in London (no names), Vol. 3 (New York: Ginko Press, 1985), 1: 14-20; and Marsilio Ficino's letter to Perregrino Agli on De divino furore.

69 André Chastel, Marsile Ficin et L'Art (Geneva: Droz, 1975), 129-33, chapter on "Furor divinus: L'inspiration."

70 See The Letters of Marsilio Ficino, Vol. 1, Letter 7, Marsilio Ficino to Peregrino Agli, On Divine Frenzy, 14-20 (no date, probably between1457 and 1476); Marsilio Ficino, Meditations on the Soul: Selected Letters of Marsilio Ficino, ed. and trans. Clement Salaman (Rochester, VT: Inner Traditions International, 1996), 64-70, on divine frenzy; Thomas Moore, The Planets Within (Hudson, NY: Lindisfarne Press, 1990), 41 and 86-87; and D. P. Walker, Spiritual and Demonic Magic: From Ficino to Campanella (University Park: The Pennsylvania State University Press, 2000), 3-11.

${ }^{71}$ Rosanna Bettarini and Paola Barocchi on the 1550 and 1568 editions of Giorgio Vasari, Le vite de’ piú eccellenti architetti, pittori, et scultori [The lives of the most excellent painters, sculptors and architects], Vol. 6 (Florence: Sansoni, 1971-1986), 3: 62: "Attesoché l'ingegno vuol essere affaticato quando l'intelleto ha voglia di operare, e che il furore è acceso, perché allora si vede uscirne parti eccellenti e divini, e concetti meravigliosi."
} 


\section{References}

Acidini Luchinat, C. (1998). Vasari’s last paintings: The cupola of Florence Cathedral, In Jacks, P. (Ed.), Vasari’s Florence: Artists and literati at the Medicean court (pp. 238-250). Cambridge: Cambridge University Press.

Allen, M. J. B. (1981). Marsilio Ficino and the Phaedran Charioteer. Berkeley: University of California Press.

Altcappenberg, Hein-Thomas S. (2000). Sandro Botticelli: The drawings for Dante's divine comedy (Vols. 1-2). London/Rome: Royal Academy of the Arts and Scuderie Papali al Quirinale.

Ariès, P. (1985). Images of man and death. Cambridge: Harvard University Press.

Arthos, J. (1963). Dante, Michelangelo and Milton. London: Routledge \& Kegan Paul.

Auerback, E. (1974). Figure. In mimesis: The representation of reality in Western literature (pp. 174-202). Princeton: Princeton University Press.

Baglione, G. (1642). Le vite de' pittori, scultori ed architetti [The lives of painters, sculptors and architects]. Rome: Andrea Fei.

Barasch, M. (1985). Zuccari: The theory of Disegno. In Theories of art: From Plato to Winckelmann. New York: New York University Press.

Barbi, M. (1890). Della fortuna di Dante nel secolo XVI [On Dante's luck in the sixteenth century]. Pisa: T. Nistri and Co.

Barocchi, P. (Ed.). (1964). I Fondatori dell'Accademia del Disegno [The founders of the academy of design]. Florence: L.S. Olschki.

Barolsky, P. (1996). The visionary art of Michelangelo in the light of Dante. In Dante Studies, 114, 1-14.

Barricelli, J. P. (1996). Dante's Inferno I in the visual arts. In Dante Studies CXIV, 14-39.

Barzman, K. E. (2001). The Florentine academy and the early modern state. The discipline of disegno. Cambridge: Cambridge University Press.

Bergin, T. G. (1964). Dante. New York: The Orion Press.

Berk, P. R. (1998). Canto VII: The wheel of fortune. In Mandelbaum, et al., Inferno: A canto-by-canto commentary (pp. 101-110). Berkeley: University of California Press.

Biagi, G. (1892/3a). Le illustrazioni alla Divina Commedia di Giovanni Stradano 1587 [The illustration of the divine comedy by Giovanni Stradano, 1587]. Florence: Fratelli Alinari.

Biagi, G. (1892b). Intro. and Symonds, J. A., preface. Dante’s illustrations for the divine comedy, executed by J. Stradanus, 1587. London: Edwards.

Biagi, G. (1924). La Divina Commedia nella figurazione artistica e nel secolare comment $\quad[$ The divine comedy in visual representations and commentary], Vol. 3. Turin: UTET.

Blunt, A. (1968). Artistic theory in Italy. Oxford: Oxford University Press.

Boas, T. S. R. (1972). Ars Moriendi [The art of dying]: Death in the middle ages. New York: McGraw-Hill Book Company.

Brieger, P., Meiss, M., \& Singleton, C. S. (1969). Illuminated manuscripts of the divine comedy. (Vols. 1-2). Princeton: Princeton University Press.

Brink. C. O. (Ed.). (1971). Horace on poetry: The ars poetica. Cambridge: Cambridge University Press.

Brooks, J. (2007). Taddeo and Federico Zuccaro: Artist-Brothers in Renaissance Rome. Los Angeles: The J. Paul Getty Museum.

Brunner, M. (1994). Alcune note sulla commissione dei disegni danteschi di Giovanni Stradano [Some notes Giovanni Stadano's commission for the Dante's drawings]. In Gizzi. Giovanni Stradano e Dante (pp. 123-132). Milan: Electa.

Cassata, L. (1998). Canto I: The hard begin. In Mandelbaum, et al., Inferno: A Canto-by-Canto commentary (pp. 9-24). Berkeley: University of California Press.

Cast, D. J. (Ed.). (2014/16). The Ashgate research companion to Giorgio Vasari. Burlington: VT: Ashgate, 2016.

Cavendish, R. (1977). Visions of heaven and hell. London: Orbis Publishing.

Ceserani, R. (1998). Canto XXXIV: Lucifer. In Mandelbaum, et al., Inferno: A Canto-by-Canto Commentary. Berkeley: University of California Press, 432-439.

Chastel, A. (1954). Marsile Ficin et L'Art [Marsilio Ficino and art]. Geneva: Droz.

Cheney, Liana D. (1987). I Disegni di Botticelli per La Divina Commedia di Dante [The drawings of Botticelli for Dante's divine comedy]. In Letteratura Italiana e Arti Figurative (pp. 1-8). Florence: Leo S. Olschki.

Cheney, Liana D. (1993). Botticelli’s Neoplatonic images. Potomac, MD: Scriptura Humanistica.

Cheney, Liana D. (1998). Dante’s Inferno. Italian Culture (Fall 1998), 35-55.

Cioffi, C. A. (1998). Canto VIII: Fifth circle: Wrathful and sullen. In Mandelbaum, et al., Inferno: A Canto-by-Canto commentary (pp. 111-122). Berkeley: University of California Press. 
Clark, K. (1976). The drawings by Sandro Botticelli for Dante's Divine comedy: After the originals in the Berlin museum and Vatican. New York: Harper \& Row, Publishers.

Cogliati Arano, L. (1976). The medieval health handbook: Tacuinum sanitatis. New York: George Braziller.

Davis, C. T. (1984). Dante's Italy and other essays. Philadelphia: University of Pennsylvania Press.

Demaray, J. C. (1977). Dante and the book of the cosmos. Philadelphia: Transactions of the American Philosophical Society.

Dixon, L. (1981/82). Music, medicine, morals: The iconography of an early musical instrument. Studies in Iconography, 7-9, 147-156.

Dreyer, P. (1984). Botticelli's series of engravings of 1481. Print Quarterly (June), 111-115.

Fairclough, H. R. (Trans.). (1929). Horace: Epistles book II and arts poetica. Cambridge: Harvard University Press.

Ferguson, E. (1953). Demonology of the early Christian world. London: The Edwin Mellen Press.

Fowlie, W. (1981). Dante's Inferno. Chicago: University of Chicago Press.

Freedberg, S. (1993). Painting in Italy: 1500-1600. Baltimore: Pelican History of Art.

Frongia, E. N. (1998). Canto III: The gate of Hell. In Mandelbaum, et al., Inferno: A Canto-by-Canto commentary (pp. 36-49). Berkeley: University of California Press.

Gere, J. (1969). Taddeo Zuccaro. Chicago: University Chicago Press.

Ginzburg, C. (1991). Ecstasies: Deciphering the witches Sabbath. Baltimore, MD: Penguin Books.

Gizzi, C. (Ed.). (1990). Botticelli e Dante [Botticelli and Dante]. Milan: Electa.

Gizzi, C. (Ed.). (1991). Signorelli e Dante. Milan: Electa.

Gizzi, C. (Ed.). (1993a). Botticelli e Dante. Milan: Electa.

Gizzi, C. (Ed.). (1993b). Federico Zuccari e Dante. Milan: Electa.

Gizzi, C. (Ed.). (1994). Giovanni Stradano e Dante. Milan: Electa.

Grandgent, C. H. (Ed.) (Trans.), \& Singleton, C. S. (1972). Dante Alighieri, La Divina Commedia. Cambridge: Harvard University Press.

Guazzo, F. M. (1988). Malleus Maleficarum [The witch hammer]. New York: Dover Publications.

Hagstrum, J. H. (1958). Sister arts: The tradition of literary pictorialism and the English poetry from Dryden to Gray. Chicago: University of Chicago Press.

Heikamp, D. (Ed.). (1961). Scritti d'Arte [Writings on art]. Florence: L.S. Olschki.

Heikamp, D. (1967). Federico Zuccaro a Firenze: 1557-1579 [Federico Zuccaro in Florence: 1557-1579]. In Paragone (March), 1-34, 44-68.

Horne, H. (1987). Botticelli, painter of Florence. Princeton: Princeton University Press.

Jacopff, R. (Ed.). (1993). The Cambridge companion to Dante. New York: Cambridge University Press.

Kanter, L. B. (1994). Painting and illumination in early Renaissance Florence, 1300-1450. New York: Metropolitan Museum of Art.

Kelly, H. A. (1968). The devil, demonology and witchcraft. New York: Doubleday \& Co.

Kieft, G. (1989). Zuccari, Scagliero e Panofsky. Mitteilungen des Kunsthistorischen Institutes in Florenz 33. 2/3, 355-68.

Kirkpatrick, R. (1987). Dante: The divine comedy. New York: Cambridge University Press.

Körte, W. (1935). Der Palazzo Zuccari in Röm [The Zuccari palace in Rome]. Leipzig: H. Keller.

Kristeller, O. (Ed.). (1985). The letters of Marsilio Ficino (Vols. 1-3). New York: Ginko Press.

Lee, R. (1967). Ut pictura poesis: Humanist theory of painting. New York: W.W. Norton and Company, Inc.

Lenzoni, A. (1994). La Biblioteca Medicea Laurenziana e il Codice Mediceo Palatino. In Gizzi, Giovanni Stradano e Dante (pp. 211-222). Milan: Electa.

Lightbown, R. (1978). Botticelli, Life and Work (Vols. 1-2). Berkeley, CA: University of California Press.

Lomazzo, G. P. (1585) Trattato dell' arte della pittura, scultura et architettura [Treatise on the art of painting, sculpture and architecture]. Milan: Paolo Gottardo Pontio.

Luke, H. M. (1989). Dark wood to white rose: Journey and transformation in Dante's Divine comedy. New York: Parabola Books.

Mandelbaum, A. (Ed. and Trans.). (1980, 1995, 2013). The divine comedy. New York: Vintage.

Mandelbaum, A., Oldcorn, A., \& Ross, C. (1998). Inferno: A Canto-by-Canto commentary. Berkeley: University of California Press.

Michelet, J. (1970). Satanism and witchcraft: A study in medieval superstition. New York: The Citadel Press.

Moeller, C. (Ed.). (1952). Satan. New York: Sheed \& Ward. 
Moore, T. (1990). The planets within. Hudson, NY: Lindisfarne Press.

Musa, M. (Ed. and Trans.). (1970-2002). Dante’s divine comedy (Vols. 1-3). Baltimore: Penguin Classics.

Nassar, E. P. (1994). Illustrations to Dante's Inferno. London: Associated University Press.

Noakes, S. (1998). Canto XVI: From other sodomites to fraud. In Mandelbaum, et al., Inferno: A Canto-by-Canto commentary (pp. 212-224). Berkeley: University of California Press.

Nohrnberg, J. (1998). Canto XVIII: Introduction to Malebolge. In Mandelbaum, et al., Inferno: A Canto-by-Canto commentary (pp. 238-261). Berkeley: University of California Press.

Panofsky, E. (1968). Zuccari: The Aristotelian-Thomistic trend. In Idea: A concept in art theory (pp. 85-93). Columbia: University of South Carolina Press.

Partridge, L. W. (1971/2). The Sala d' Ercole in the Villa Farnese at Caprarola. In Art Bulletin (December), 467-86 (March), 50-62.

Partridge, L. W. (1978). Divinity and dynasty at Caprarola: Perfect history in the room of Farnese deeds. In Art Bulletin (September), 449-530.

Pastore Stocchi, M. (1998). Canto IV: A melancholy Elysium. In Mandelbaum, et al., Inferno: A Canto-by-Canto commentary (pp. 50-62). Berkeley: University of California Press.

Pilliod, E. (2001). Pontormo, Bronzino and Allori: A genealogy of Florentine art. London: Yale University Press.

Pinsky, R. (1994-1996). The Inferno of Dante. New York: Farrar, Straus \& Giroux.

Pope-Hennessy, J. (1993). Paradiso: The illuminations of Dante’s divine comedy by Giovanni di Paolo. New York: Random House.

Praz, M. (1967). Mnemosyne the parallel between literature and the visual arts. Princeton: Princeton University Press.

Quinones, R. J. (1994). Foundation sacrifice in Dante's commedia. University Park: The Pennsylvania State University Press.

Ricci, C. (1891). Ultimo Rifugio di Dante Alighieri con illustrazioni e documenti [The last refuge of Dante Alighieri with illustrations and documents]. Milan: U. Hoepli.

Ricci, C. (1908). La Divina Commedia di Dante Alighieri nell'arte del Cinquecento [The Divine comedy of Dante Alighieri in the art of sixteenth century]. Rome: Fratelli Treves Editori.

Rickter, J. P. (Ed.). (1883). The Literary Works of Leonardo da Vinci (Scritti Letterari di Leonardo da Vinci cavati dagl autografi e pubblicati). London: Sampson Low, Marston, Searle \& Rivington.

Roskill, R. (Trans.). (1968). Dolce’s Dialogo della Pittura (1557) [Dolce’s dialogue on painting, 1557]. New York: New York University Press.

Salaman, C. (Ed. and Trans.). (1996). Marsilio Ficino, meditations on the soul: Selected letters of Marsilio Ficino. Rochester, VT: Inner Traditions International.

Sanguineti, E. (1998). Canto XXXIII: Count Ugolini and others. In Mandelbaum, et al., Inferno: A Canto-by-Canto commentary (pp. 424-431). Berkeley: University of California Press.

Sears, J. (1952). Ficino and the Platonism of the English Renaissance. Comparative Literature 4 (Summer), 214-238.

Singleton, C. S. (Ed. and Trans.). (1970-1991). Dante's divine comedy. Princeton: Princeton University Press.

Spencer, J. R. (1957). Ut rhetorica pictura: A study in quattrocento theory of painting. Journal of the Warburg and Courtauld Institutes, 20, 26-44.

Taylor, C. H., \& Finely, P. (1997). Images of the journey in Dante's divine comedy. London: Yale University Press.

Tetel, M., Witt, R. G., \& Goffen, R. (Ed.). (1989). Life and death in fifteenth-century Florence. Durham: Duke University Press.

Trevor-Roper, H. R. (1977). The European witch-craze. New York: Harper \& Row Publishers.

Trottein, S. (2012). L’idée des Artistes: Panofsky, Cassirer, Zuccaro et la théorie de l'art [Artists' ideas: Panofsky, Cassirer and Zuccaro and the theory of art]. In Racar/Société pour Promouvoir la Publication en Histoire de l'Art au Canada, 37(2), 19-26.

Turner, A. K. (1993). The history of hell. New York: Harcourt Brace \& Company.

Vasari, G. (1550 and 1568). Le vite de' piú eccellenti architetti, pittori, et scultori [The lives of the most excellent painters, sculptors and architects]. R. Bettarini and P. Barocchi (Eds.) (1971-1986) (Vols. 1-6). Florence: S.P.E.S.

Vasari, G. (1568). Le vite de' piú eccellenti pittori, scultori ed architettori [The lives of the most excellent painters, sculptors and architects]. Florence: Giunti.

Vasari, G. (1568). Le vite dei più eccellenti pittori, scultori ed architettori [The lives of the most excellent painters, sculptors and architects], G. Milanesi (Ed.). (1906/73) (Vols. 1-9). Florence: G. S. Sansoni.

Venturi, A. (1921). Il Botticelli: Interprete di Dante [Botticelli: Intepreter of Dante]. Florence: Felice Le Monnier. 
Volkmann, L. (1899). Iconografia dantesca; the pictorial representations to Dante’s Divine Comedy. C. Sarolea. (Ed. and Trans.). London: H. Grevel \& Co. (Reprint of 1892).

Walker, D. P. (2000). Spiritual and demonic magic: From Ficino to Campanella. University Park: The Pennsylvania State University Press.

Watts, B. J. (1989). Studies in Sandro Botticelli's drawings for Dante’s Inferno. (Ph.D. diss., University of Virginia).

Watts, B. J. (1995). Sandro Botticelli’s Drawings for Dante's Inferno: Structure, topography, and manuscript design. Artibus et Historiae, 16(32), 163-201.

Watts, B. J. (1995). Sandro Botticelli's Illustrations for Inferno VIII and IX: Narrative revision and the role of manuscript tradition. Word and Image A Journal of Verbal/Visual Enquiry, (April-June), 149-173.

Watts, B. J. (1996). Artistic competition, hubris, and humility: Sandro Botticelli’s response to visibile parlare. In Dante Studies, 114, 41-79.

Watts, B. J. (1998). Pictorial wit and parody as narrative tools: Botticelli’s drawings for Dante’s Inferno. (Oral presentation at the Boston Dante Society).

Watts, B. J. (1998). The word imaged: Dante’s Commedia and Sandro Botticelli's San Barnaba altarpiece. In Lectura Dantis, 22-23, 203-245.

Wazbinski, Z. (1987). L'Accademia medicea del Disegno a Firenze nel Cinquecento [The medicean academy of design in Florence in the sixteenth century]. Florence: L.S. Olschki.

Zuccaro, F. (1607). L'Idea de'Pittori, Scultori ed Architteti [The idea of painters, sculptors and architects] (Vols. 1-2). Turin: Agostino Disserolio. 